\title{
Mutant p53 melanoma cell lines respond differently to CP-31398-induced apoptosis
}

by

\author{
CLEMENT KAR-MING HO
}

B.Sc., The University of British Columbia, 2000

B.Ed., The University of British Columbia, 2001

A THESIS SUBMITTED IN PARTIAL FULFILMENT OF THE REQUIREMENTS FOR THE DEGREE OF

\section{MASTER OF SCIENCE}

in

THE FACULTY OF GRADUATE STUDIES

(Experimental Medicine)

THE UNIVERSITY OF BRITISH COLUMBIA

April 2005

(C) Clement Kar-ming Ho, 2005 


\begin{abstract}
$p 53$, a tumour suppressor gene, is considered the guardian of genome which governs several important biological functions including cell cycle arrest, DNA repair and apoptosis. Under normal conditions, p53 is tightly regulated and constitutively expressed at a low level. In human cancers, $p 53$ is one of the most frequently mutated genes with over $50 \%$ of all human malignancies containing an altered $p 53$ gene.

Many strategies have been developed in light of restoring wild-type p53 functions to altered p53. Recently, a small pharmacological compound, CP-31398, was found through random screening to have the ability to promote proper p53 protein folding, activate p53 transcription of downstream targets, and slow tumor growth in mice. Additionally, CP-31398 was found to be able to convert mutant p53 to wild-type conformation in several cell lines.
\end{abstract}

In this study, we sought to examine if CP-31398 can revert all mutant p53 proteins to wild-type function. We studied a series of apoptotic responses to CP-31398 in three melanoma cell lines with various p53 mutation status. Upon a moderate dose of CP-31398 treatment $\left(15 \mu \mathrm{g} \mathrm{mL}^{-1}\right)$, only the wild-type p53 MMRU and the single p53 point mutation MeWo cells exhibited apoptosis. Another melanoma cell line, Sk-mel110 , containing multiple p53 mutations did not exhibit apoptosis. Despite CP-31398 enhanced overall p53 protein level, its ability to promote proper folding of p53 protein was limited to CP-31398 sensitive MMRU and MeWo cells. Although all cell lines showed an increased $\mathrm{p} 21^{\text {Wafl }}$ transcription, only sensitive cells showed an increased Bax and PUMA transcription, an altered mitochondrial membrane potential, followed by the 
release of cytochrome $c$, and cleaved caspases-9 and -3 . We also demonstrated that Apaf-1, Fas and Fas-ligand were not involved in CP-31398 mediated apoptosis.

In Summary, our results suggest that the ability of CP-31398 to revert mutant p53 proteins to wild-type conformation may be correlated to $p 53$ mutation status. Mutant p53 reactivation by small molecules has an evident potential for the discovery of effective and specific anti-cancer drugs. To investigate $p 53$ mutation-dependent in response to CP31398 , further studies are required to explore the possibility of utilizing this compound as an anti-cancer therapeutic agent. 


\section{TABLE OF CONTENTS}

Abstract $\quad$ ii

Table of Contents $\quad$ iv

List of Tables $\quad$ vi

List of Figures vii

List of Abbreviations viii

$\begin{array}{ll}\text { Acknowledgments } & \text { ix }\end{array}$

$\begin{array}{ll}\text { Chapter } 1 \text { - General Introduction } & 1\end{array}$

1.1. Melanoma 1

1.1.1. Introduction 1

1.1.2. Aetiology of melanoma 2

1.2. p53 - the guardian of genome 4

1.2.1. Gene and protein structure 4

1.2.2. Regulation and post-translational modification of p53

1.2.3. Cell cycle arrest and p53 8

1.2.4. Apoptosis and p53 9

$\begin{array}{ll}\text { 1.2.5. Cancer and } \mathrm{p} 53 \text { mutation } & 12\end{array}$

$\begin{array}{ll}\text { 1.2.6. } & \text { Chemotherapy and p53 } \\ & 13\end{array}$

1.3. CP-31398 - a p53 stabilizing compound 14

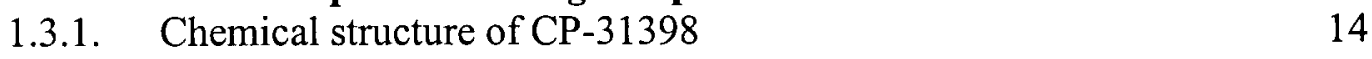

1.3.2. Function of CP-31398 16

$\begin{array}{lr}\text { Chapter } 2 \text { - Material and methods } & 18\end{array}$

$\begin{array}{lll}2.1 & \text { Materials } & 18\end{array}$

$\begin{array}{lll}2.1 .1 & \text { Cell lines } & 18\end{array}$

$\begin{array}{ll}2.1 .2 & \text { Reagents, and chemicals } \\ \end{array}$ 
$\begin{array}{lll}2.2 & \text { Methods } & 19\end{array}$

$\begin{array}{lll}2.2 .1 & \text { Cell survival assay } & 19\end{array}$

$\begin{array}{ll}2.2 .2 & \text { Propidium iodide staining } \\ 2.39\end{array}$

$\begin{array}{ll}2.2 .3 & \text { DNA fragmentation assay }\end{array}$

$\begin{array}{lll}2.2 .4 & \text { Immunofluorescent staining } & 21\end{array}$

2.2.5 Mitochondrial transmembrane potential detection 21 (MitoCapture ${ }^{\mathrm{TM}}$ )

2.2.6 Western blot analysis $\quad 22$

2.2.7 Subcellular fractionation 23

2.2.8 Reverse transcriptase-polymerase chain reaction (RT-PCR) 24

Chapter 3 - The Ability of CP-31398 to revert mutant p53 to wild-type p53 26 conformation may not be universal

$\begin{array}{ll}3.1 & \text { Rationale and Hypothesis }\end{array}$

3.2 Results $\quad 30$

3.2.1 Effects of CP-31398 on survival of human melanoma cells 30

3.2.2 Differential responses of mutant p53 melanoma cell lines to CP- $\quad 34$ 31398-induced apoptosis

3.2.3 Restoration and stabilization of $\mathrm{p} 53$ wild-type conformation 38

$\begin{array}{lll}3.2 .4 & \text { Activation of } \mathrm{p} 53 \text { transcriptional activity } & 42\end{array}$

3.2.5 Alteration of mitochondrial transmembrane potential 44

3.2.6 Induction of cytochrome $c$ release 46

3.2.7 CP-31398 does not induce Apaf-1 expression 48

3.2.8 Activation of Caspase-9 and -3 48

3.2.9 CP-31398-induced apoptosis does not involve Fas receptor or $\quad 50$ Fas-ligand

$\begin{array}{lll}3.3 & \text { Discussion } & 52\end{array}$

$\begin{array}{lr}\text { Chapter 4 - General Conclusion } & 58\end{array}$

$\begin{array}{lll}4.1 & \text { Summary } & 58\end{array}$

$\begin{array}{lll}4.2 & \text { Future directions } & 60\end{array}$

References $\quad 62$ 


\section{LIST OF TABLES}

Table 3.1 Description of $\mathrm{p} 53$ mutation status found in melanocytic lesions. 


\section{LIST OF FIGURES}

Figure 1.1 A schematic representation of the $\mathrm{p} 53$ protein. 6

Figure 1.2 Chemical structure of p53-stabilizing compound, CP-31398. 15

Figure 3.1 Survival of human melanoma cells after CP-31398 treatment is 32 dose dependent.

Figure 3.2 Alteration in survival of human melanoma cells after CP-31398 33 treatment.

Figure 3.3 CP-31398 induces DNA fragmentation in human melanoma cells.

Figure 3.4 CP-31398 induces apoptosis in human melanoma cells.

Figure 3.5 CP-31398 increases sub-G1 cell population in human melanoma cells.

Figure 3.6 Effect of CP-31398 on the overall expression of p53 proteins in 40 human melanoma cells.

Figure 3.7 Effect of CP-31398 on the expression of $\mathrm{p} 53$ proteins in human 41 melanoma cells.

Figure 3.8 Effect of CP-31398 on p21 ${ }^{\text {Wafl }}$, Bax and PUMA mRNA levels. 43

Figure 3.9 CP-31398 alters the mitochondrial membrane potential. 45

Figure 3.10 Effect of CP-31398 on cytochrome $c$ release. 47

Figure 3.11 Effect of CP-31398 on the expression of Apaf-1, pro-caspases-9 49 and -3 .

Figure 3.12 CP-31398 did not alter the expression of Fas and Fas-lignad proteins. 


\section{LIST OF ABBREVIATIONS}

Apaf-1

BER

BH3

BSA

CDK

DBD

DED

DISC

DR5

$\mathrm{EC}_{50}$

$\mathrm{EtBr}$

FADD

GADD45

GAPDH

HRP

Mdm2

NER

NMR

p53R2

PAGE

PBS

Pgp

PI

PIG

$\mathrm{Pu}$

PUMA

PVDF

Py

$\mathrm{Rb}$

ROS

RT-PCR

SRB

TBS

TCA

TNFR1

TRAIL

UV

UVR apoptotic protease activating factor-1

Base excision repair

Bcl-2 homology 3

Bovine serum albumin

Cyclin-dependent kinase

DNA binding domain

Death effector domain

Death inducing Signalling Complex

Death receptor 5

Effective concentration 50\%

Ethidium bromide

Fas-associated Death Domain

Growth arrest and DNA damage protein

Glyceraldehyde-3-phosphate dehydrogenase

Horseradish peroxidase

Mouse double minute 2

Nucleotide excision repair

Nuclear magnetic resonance

p53-inducible ribonucleotide reductase small subunit 2 homolog

Polyacrylamide gel electrophoresis

Phosphate buffered saline

P-glycoprotein

Propidium iodide

p53-inducible genes

Purine

p53 upregulated modulator of apoptosis

Polyvinylidene difluoride

Pyrimidine

Retinoblastoma protein

Reactive oxygen species

Reverse transcriptase-polymerase chain reaction

Sulforhodamine B

Tris buffered saline

Trichloroacetate

Tumour necrosis factor receptor type 1

TNF-related apoptosis-inducing ligand

Ultraviolet

Ultraviolet radiation 


\section{ACKNOWLEDGEMENT}

I would like to thank my supervisor, Dr. Gang Li, for granting me the opportunity to explore and emerge myself in this exciting world of scientific research. His intellectual stimulation, encouragement and occasion to attend international conferences have allowed me to see the diversity and the depth of basic science can reach. To Dr. Vincent Ho, Dr. William Jia, Dr. Paul Rennie, and Dr. Chris Ong, I truly appreciate your input and involvement in my committee. Your suggestions and feedbacks have widened my understanding and scope of research work tremendously. As for the members of the $\mathrm{Li}$ lab, you have become my second family while we spent countless hours working side by side. Without your kindness, thoughtfulness, respect and friendship, I would not be able to endure all those long hours at my bench top persevering through my experiments. Above all, I am privileged to have the continuous support, unconditional love and ceaseless understanding from my parents, my brother, and my friends time after time. You have given me the strength to strive so that I can give a hundred and ten percent in everything I do. For that, thank you from the bottom of my heart. 


\section{CHAPTER 1. GENERAL INTRODUCTION}

\section{$1.1 \quad$ Melanoma}

\subsubsection{Introduction}

The skin is the largest organ covering the entire surface of the body consisting of elements of ectodermal, mesodermal and endodermal origin. One of the main functions of the skin is protection. It protects the body from external factors such as bacteria and surroundings. The skin contains secretions that can kill bacteria and the melanin provides a chemical pigment defense against ultraviolet (UV) light that can damage skin cells.

The skin can be divided into three major layers: epidermis, dermis, and the subcutaneous layer. The epidermis is the thin outer layer of the skin, which can be further divided into three sub-layers. The status corneum or horny layer, which contains mostly dead keratinocytes, protects the skin from harmful elements. Below this is a layer of living keratinocytes or squamous cells, which help provide the skin with what it needs to protect the rest of the body. The basal layer is the inner layer of the epidermis which contains basal cells. Basal cells continually divide, forming new keratinocytes and replacing the old ones that are shed from the skin's surface. The epidermis also contains melanocytes, which are cells that produce a brown-black skin pigment called melanin that determines skin and hair coloring. In fact, it is the melanin that helps protect against the damaging rays of the sun. The dermis is the middle layer of the skin which contains blood and lymph vessels, hair follicles, sweat glands, as well as pain and touch receptors. The subcutaneous layer is the deepest layer of skin consisting of a network of collagen and fat cells, which helps 
conserve the heat of the body while protecting other organs from injury by acting as a shock absorber.

Such a diverse group of tissues gives rise to a wide variety of benign and malignant tumours that contribute to the most common cancer among all type of cancers (Boni et al., 2002). In 2003 alone, over 80,000 cases of skin cancer were diagnosed in Canada, in which 76,000 cases were non-melanoma skin cancer including basal cell carcinoma and squamous cell carcinoma, both of which originate from keratinocytes, and 4,250 cases were melanoma which originates from melanocytes (National Cancer Institute of Canada: Canadian Cancer Statistics 2004, Toronto, Canada, 2004).

Although malignant melanoma contributes about $5 \%$ of all skin cancer cases, its incidence and mortality rate have been rising steadily in the past few decades. A stunning report indicated that the probability of an American developing melanoma during his/her lifetime leaped from one in 1,500 in 1960, to one in 68 in 2000, and is projected to increase to 1 in 50 by the year 2010 (Rigel et al., 1996; Rigel, 2002; Dunlap et al., 2004). The development of melanoma has been associated with intermittent acute sunlight exposure causing severe sunburns particularly during childhood or adolescence (Holman and Armstrong, 1984; Kricker et al., 1995). It is characterised by skin lesions or abnormal growth that the appearance changes over time. Besides a mixture of colours in one lesion, the borders are often irregular and asymmetrical.

\subsubsection{Aetiology of melanoma}

Melanoma is derived from an uncontrolled proliferation of transformed pigment-producing melanocytes. The major environmental factor for the development of cutaneous melanoma 
is believed to be UV radiation (UVR) (Romerdahl et al., 1988; Atillasoy et al., 1998). UVR causes DNA damage in the forms of cyclobutane pyrimidine dimers and/or (6-4) photoproducts (Alcalay et al., 1990). The development of melanoma can be linked to intermittent over-exposure to UVR causing painful sunburns particularly in the childhood (Holman and Armstrong, 1984). In fact more than $80 \%$ of melanoma cases in Australia are estimated to be triggered by over sun exposure (Armstrong and Kricker, 1993).

Patients with malignant melanoma have a poor prognosis even when treated with a combination of therapies. Advanced melanoma has been associated with one of the highest mortality rates with a 5-year patients' survival rate less than 10\% (Roses et al., 1991b). One of the reasons is due to the highly metastatic nature of malignant melanoma. Melanoma cells infiltrate from the skin and spread rapidly to other organs such as lung, liver, brain, bone and small intestine. The escalating high mortality rate is further compounded by the highly resistant nature of malignant melanoma to traditional radiation and chemotherapy (Garbe, 1993; Schadendorf et al., 1994; Serrone and Hersey, 1999; Helmbach et al., 2001). Currently, no effective treatment is available once melanoma metastasizes.

Although the molecular mechanisms involved in melanoma and chemoresistance have not been identified, it is assumed that inhibition or dysregulation of apoptosis leads to chemoresistance (Serrone and Hersey, 1999). Unlike non-melanoma skin cancers, p53 mutation is rare: less than $5 \%$ in primary melanoma, and approximately $20 \%$ in metastatic melanoma (Hussein et al., 2003). The most common known genetic alterations is the deletion of chromosomal region $9 \mathrm{q} 21$, which harbours tumour suppressors $\mathrm{p} 16^{I N K 4 a}$ and $\mathrm{p} 14^{A R F}$, detected in about $50 \%$ in melanoma (Healy et al., 1996; Rizos et al., 2001). Loss 
of $\mathrm{p} 16^{I N K 4 a}$ instead of $\mathrm{p} 14^{A R F}$ appears to be a more consistent target in general (FitzGerald et al., 1996). Inactivation of $\mathrm{p} 16^{I N K 4 a}$, an inhibitor of cyclin-dependent kinase 4 (CDK4), could lead to the hyperactivity of retinoblastoma $(\mathrm{Rb})$ and $\mathrm{E} 2 \mathrm{~F}-1$ transcription factor; thus stimulating cell cycle progression. The decreased protein expression of $\mathrm{p} 14^{A R F}$ from benign melanocytic nevi to metastatic melanoma suggests that inactivation of $\mathrm{p} 14^{A R F}$ may be an important event in melanoma progression (Dobrowolski et al., 2002). Moreover, the loss of function of $\mathrm{p} 14^{A R F}$, an inhibitor of $\mathrm{Mdm} 2$, may disrupt $\mathrm{p} 53$ protein stability (de Gruijl et al., 2001).

Recently, Apaf-1 (apoptotic protease activating factor-1) has also been linked to the development of melanoma (Soengas et al., 2001). Apaf-1 is a pro-apoptotic adaptor protein that complexes with cytochrome $c$ and pro-caspase 9 to form apoptosome that mediates apoptosis. Allelic deletion of Apaf-1 is observed in $40 \%$ of malignant melanoma cases (Hussein et al., 2003). Furthermore, a loss of Apaf-1 expression has been associated with chemoresistance in metastatic melanoma when cancerous cells escape from p53dependent apoptosis (Soengas et al., 2001).

\section{$1.2 \mathrm{p53}$ - the guardian of genome}

\subsubsection{Gene and protein structures}

The p53 gene was discovered in the late 1970 s and mapped to chromosome $17 \mathrm{p} 13.1$ in humans that spans 20 kilobases with 11 exons. It is a cellular phosphoprotein with a relative molecular mass of approximately $53 \mathrm{kDa}$; hence, the p53 protein was so named (Lane and Crawford, 1979). Further work established that p53 is present at low levels in normal cells and higher levels in tumours and tumour derived cell lines. Initial findings 
even suggested that increased levels of p53 might contribute to cancer. Gene transfer studies further demonstrated that $p 53$ functioned as an oncogene in in vitro experiments (Eliyahu et al., 1984; Lane and Benchimol, 1990). However, subsequent studies confirmed that $\mathrm{p} 53$ was in reality a tumour-suppressor gene. The first definitive evidence for this conjecture came from the studies of human tumours (Baker et al., 1989).

p53 protein is a sequence-specific transcription factor that modifies the transcription of an ever growing large number of genes (Fields and Jang, 1990; Farmer et al., 1992; el-Deiry, 1998). This protein could be divided into various domains structurally and functionally (Figure 1.1). The transcriptional activation (TA) domain, which recruits basal transcriptional machinery required for transcribing new mRNA, consists of the first 42 amino acid residues at the $\mathrm{N}$-terminus (Unger et al., 1992). A proline-rich (P) domain consisting of residues 61 to 94 follows the transcriptional domain. The DNA binding domain (DBD) is made up of residues 102 to 292 (Bargonetti et al., 1993; Pavletich et al., 1993; Wang et al., 1993). The p53 consensus binding site consists of two copies of a 10bp motif, 5'-PuPuPuC(A/T)(T/A)GPyPyPy-3', separated by 0-13 bp (el-Deiry et al., 1992). The tetramerization (TD) domain consisting of residues 324-355. This domain is required for $\mathrm{p} 53$ protein oligmerization and DNA binding (Iwabuchi et al., 1993; Wang et al., 1994). Finally, at the C-terminus are residues 363 to 393 consisting of basic amino acids that make up a negative regulatory $(\mathrm{R})$ domain. 
Figure 1.1 A schematic representation of the $\mathrm{p} 53$ protein. TA: transactivation domain, P: proline-rich domain, DBD: DNA binding domain, TD: tetramerization domain, and R: regulatory domain.

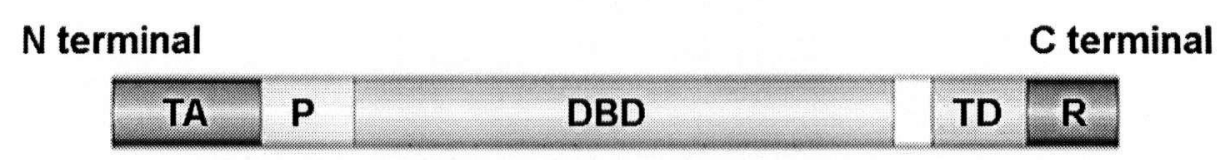




\subsubsection{Regulation and post-translational modification of p53}

Under normal conditions, p53 protein is constitutively expressed in almost all cell types. Due to its rapid turnover rate and its relatively short half-life of less than 30 minutes, the overall concentration inside a cell at any time is usually low. p53 protein is frequently in a latent form that lacks the ability to bind DNA or transactivate other genes.

One of the p53 regulators is Mdm2 (mouse double minute 2) oncoprotein (Barak et al., 1993; Wu et al., 1993). Under normal conditions, an increase in p53 protein level causes an elevated expression of Mdm2, which in turn targets $\mathrm{p} 53$ proteins for degradation. This downstream effector of $\mathrm{p} 53$ forms a negative feedback loop by binding to the transactivation domain of p53 (Momand et al., 1992; Oliner et al., 1993; Chen et al., 1995). By shuttling p53 from the nucleus to the cytoplasm, Mdm2 mediates p53 turnover (Freedman and Levine, 1998; Tao and Levine, 1999a) and targets p53 for degradation via the ubiquitin-26S proteosome (Haupt et al., 1997; Honda et al., 1997; Kubbutat et al., 1997; Fuchs et al., 1998).

Another protein involved in the regulation of p53 via Mdm2 is the tumour suppressor $\mathrm{p} 14^{A R F}$, which is encoded by an alternative reading frame in the $C D K N 2 A / I N K 4 a-A R F$ locus. $\mathrm{p} 14^{A R F}$ binds $\mathrm{Mdm} 2$ and directly inhibits Mdm2 activity without preventing the Mdm2-p53 interaction. It also prevents the ubiquitin ligase activity of Mdm2 to inhibit p53 degradation, thus increasing the half-life and activity of p53 (Kamijo et al., 1998; Pomerantz et al., 1998; Honda and Yasuda, 1999). p14 ${ }^{A R F}$ has the ability to relocalize Mdm2 to the nucleolus to prevent nuclear export of $\mathrm{p} 53$ (Tao and Levine, 1999b; Weber et al., 1999) and to promote Mdm2 degradation (Zhang et al., 1998). 


\subsection{3 p53 and cell cycle arrest}

The p53 protein is a tumour suppressor involved in many cellular processes. Although it may yet be found to have other functions, the $\mathrm{p} 53$ protein has been shown to function as a transcriptional regulatory protein (el-Deiry, 1998; Vogelstein et al., 2000). p53 activates transcription of a number of genes with roles in the control of cell cycle, including $p 21^{\text {Wafl }}$ (which encodes a regulator of CDK activity) (el-Deiry et al., 1993), GADD45 (a growtharrest DNA damage-inducible gene) (Kastan et al., 1992), Mdm2 (a negative regulator of p53 protein), and 14-3-3 $\sigma$ (a regulator of $\mathrm{G}_{2} / \mathrm{M}$ progression) (Hermeking et al., 1997).

p21 $1^{\text {Wafl }}$ activates both $\mathrm{G}_{1}$ and $\mathrm{G}_{2}$ cell cycle arrest by binding to a number of cyclinCDK complexes involved in cell cycle transitions to inhibit kinase activity (Harper et al., 1993; Sherr and Roberts, 1995; Fotedar et al., 1996; Nakanishi et al., 1997; Bates et al., 1998; Dulic et al., 1998; Niculescu et al., 1998). $\mathrm{G}_{1}$ CDKs are involved in the phosphorylation regulation of the $\mathrm{Rb}$ tumour suppressor protein. When unphosphorylated, $\mathrm{Rb}$ protein binds to E2F transcription factors to inhibit the activation of E2F-responsive target genes that are involved in the promotion of proliferation (Chellappan et al., 1991; DeGregori et al., 1995). Phosphorylation of $\mathrm{Rb}$ by $\mathrm{G}_{1} \mathrm{CDK}$ complexes allows E2F to transactive genes required for progression through the cell cycle (Sherr and Roberts, 1995). Recently, p21 ${ }^{\text {Wafl }}$ has been shown to directly bind to the E2F subunits and inactivate its transcriptional activity, independent of CDK regulation of $\mathrm{Rb}-\mathrm{E} 2 \mathrm{~F}$ interaction (Delavaine and La Thangue, 1999).

p53 is also involved in both nucleotide excision repair which repairs UV-induced DNA damage such as pyrimidine dimers, and base excision repair which removes damaged bases through alkylating agents, oxygen-free radicals or hydrolysis (Ford and 
Hanawalt, 1995; Wani et al., 1999; Offer et al., 2001; Zhou et al., 2001). p53 transactivates DNA repair genes, such as $G A D D 45$ and $p 53 R 2$, a ribonucleotide reductase gene (Smith et al., 1994; Nakano et al., 2000; Tanaka et al., 2000). Furthermore, the Cterminus of p53 binds directly to different forms of DNA damage, such as single-stranded DNA, ends of double-strand breaks, and DNA insertion or deletion mismatches.

\subsection{4 p53 and apoptosis}

Besides cell cycle arrest and DNA repair, p53 participates in the regulation of apoptosis or programmed cell death as well. Apoptosis can be triggered by a variety of physiological signals that is closely regulated in highly conserved molecular pathways. It occurs under normal conditions especially during embryonic development, metamorphosis, differentiation, and general cell turnover. Two well-characterized apoptotic pathways exist: the intrinsic or mitochondrial, and the extrinsic or death receptor pathways. Numerous studies have implicated p53 as an important protein required in apoptosis in experimental models in vitro (Lotem and Sachs, 1993; Lowe et al., 1993). p53-dependent apoptosis has also been observed in vivo (Symonds et al., 1994; Ziegler et al., 1994; Tron et al., 1998b).

p53 has been shown to take part in the mitochondrial-mediated apoptotic pathway (Shen and White, 2001) through regulation of members of the mitochondrial proteins, such as Bax and PUMA (Miyashita et al., 1994a; Miyashita et al., 1994b; Miyashita and Reed, 1995; Green and Reed, 1998). The homodimerization and heterodimerization of these proteins can lead to a change in the mitochondrial membrane potential and the sequential release of cytochrome $c$ from the intermembrane space of the mitochondria into the 
cytoplasm (Oltvai et al., 1993; Liu et al., 1996; Jurgensmeier et al., 1998; Pastorino et al., 1998; Rosse et al., 1998; Shimizu et al., 1999). Released cytochrome $c$ can then bind to the cytoplasmic scaffolding protein Apaf-1, further causing an ATP/dATP-dependent conformational change that allows Apaf-1 to bind to the pro-domain of pro-caspase-9. An apoptosome is formed and pro-caspase-9 is activated through self-cleavage (Li et al., 1997b; Rodriguez and Lazebnik, 1999; Saleh et al., 1999; Stennicke et al., 1999; Zou et al., 1999; Jiang and Wang, 2000). Caspase-9 is an initiator caspase that is part of a cysteine-dependent aspartate-directed protease family. Caspases are synthesized as inactive zymogens and activated by proteolysis (Earnshaw et al., 1999). An active caspase-9 can further initiate a cascade of proteolytic activation of other downstream effector caspases, first by cleaving pro-caspases- 3 and -7 , followed by pro-caspase- 6 cleavage by active caspase-3.

These activated caspases represent the final event in the chain reaction of apoptosis. Cellular substrates including structural proteins, such as lamin B and actin, signalling proteins, and regulators of DNA replication or transcription are cleaved (Rosen and Casciola-Rosen, 1997). The morphological characteristics of apoptosis manifested by these molecular pathways include cell shrinkage, membrane blebbing, chromatin condensation and DNA fragmentation (Wyllie et al., 1980).

p53 has recently been shown to be involved in other aspects of the mitochondrial pathway. p53 can transcriptionally regulate PUMA (p53 upregulated modulator of apoptosis) (Nakano and Vousden, 2001; Yu et al., 2001), and Apaf-1 (Moroni et al., 2001; Rozenfeld-Granot et al., 2002). PUMA has a $\mathrm{BH} 3$ or Bcl-2 homology 3 domain that mediates its interaction with Bcl-2 family member proteins, which can be localized to the 
mitochondria, and induces cytochrome $c$ release and apoptosis (Nakano and Vousden, 2001; Yu et al., 2001). In addition, p53 increases the expression of PIGs (p53-inducible genes), which are believed to encode proteins that generate or respond to oxidative stress (Polyak et al., 1997). These proteins may be involved in the production of reactive oxygen species (ROS) that lead to alterations of the mitochondrial membrane and release of cytochrome $c$ or other polypeptides into the cytoplasm. Interestingly, a recent study showed that p53 itself localizes to the mitochondria prior to changes in mitochondrial membrane potential, cytochrome $c$ release and pro-caspase- 3 activation during $\mathrm{p} 53$ dependent apoptosis (Marchenko et al., 2000).

Finally, p53 has been suggested to be involved in the Fas (also known as APO-1 or CD95) death receptor-mediated apoptotic pathway (Nagata, 1997; Ashkenazi and Dixit, 1998). Upon binding to its natural ligand, Fas ligand (Fas-L), the Fas receptor trimerizes and recruits the adaptor FADD (Fas-associated Death Domain) to its cytoplasmic death domain (Chinnaiyan et al., 1995). FADD then recruits the initiator caspase, caspase-8, to the DISC (Death Inducing Signalling Complex) via its DED (Death Effector Domain) (Muzio et al., 1996; Medema et al., 1997). Caspase-8 is activated by autocatalytic cleavage (Muzio et al., 1998), followed by activation of downstream executioner caspases, such as pro-caspases-3, -6 and -7 , and apoptosis (Hirata et al., 1998). The Fas pathway has been shown to be involved in p53-dependent apoptosis in response to various stimuli in some systems (Owen-Schaub et al., 1995; Muller et al., 1997; Bennett et al., 1998; Muller et al., 1998a; Muller et al., 1998b; Fukazawa et al., 1999; Hara et al., 2000; Embree-Ku et al., 2002; Lorenzo et al., 2002). Others have shown that p53 can induce apoptosis independently of the Fas pathway (Fuchs et al., 1997; Reinke and Lozano, 1997). p53- 
dependent apoptosis may involve other members of the death receptor family, such as TNFR1 (tumour necrosis factor receptor type 1) (Inagaki-Ohara et al., 2001) and the TRAIL (TNF-related apoptosis-inducing ligand) death receptor KILLER/DR5 (Wu et al., 1997; Wu et al., 1999).

\subsection{5 p53 mutation in human cancers}

Current studies suggest that the loss of normal p53 function is associated with cell transformation in vitro (Eliyahu et al., 1989; Finlay et al., 1989; Baker et al., 1990) and neoplasms development in vivo (Donehower et al., 1992; Symonds et al., 1994). In sporadic cancers in human, $p 53$ has been shown to be one of the most frequently mutated genes (Hollstein et al., 1991; Hollstein et al., 1996). In fact, over 50\% of human malignancies in epithelial, mesenchymal, haematopoitic, lymphoid, and nervous origin analyzed to date were shown to contain an altered p53 gene (Hollstein et al., 1996; Soussi, 2000). Inborn germline mutations in the human $p 53$ gene can result in Li-Fraumeni syndrome, which is a hereditary cancer susceptibility syndrome leading to a predisposition to sarcomas, lymphomas, breast, brain and other tumours at an early age (Malkin et al., 1990; Srivastava et al., 1990). In animal model, $p 53$ homozygous and hemizygous knockout mice have a near normal development, but with a number of genetic alterations, including gene amplification and abnormal chromosome numbers. These mice are also more prone to develop multiple tumours at a young age (Donehower et al., 1992; Fukasawa et al., 1997). Overall, inactivation of the 553 pathway seems to be a common mechanism in the development of cancer. 
Most mutations in the $p 53$ gene are missense mutations producing a stable yet nonfunctional protein. Some mutations even lead to a gain of oncogenic function or dominant negative phenotype over wild-type p53 through heterotetramerization (Dittmer et al., 1993; Hachiya et al., 1994; Brachmann et al., 1996; de Vries et al., 2002). Mutant p53 protein folds into conformations that are not recognized by PAb1620 (Milner and Medcalf, 1990), a conformation-specific monoclonal antibody that recognizes only the wild-type p53 conformation. Due to the fact that most $p 53$ mutations are found within the core DNA binding domain (Cho et al., 1994; Hollstein et al., 1996), the transcribed protein usually cannot bind to DNA and has impaired transactivation function. This suggests that $\mathrm{p} 53$ DNA binding and transcriptional activation are critical in the response to DNA damage and other various p53 functions (Pietenpol et al., 1994). In some cancers with unaltered p53 genes, p53 maý be inactivated indirectly through binding to viral proteins. Others may have gene products upstream or downstream of p 53 altered.

\subsection{6 p53 and chemotherapy}

Currently many different forms of chemotherapy are available. They target various biochemical sites such as thymidylate synthase inhibitors, microtubule damage, topoisomerase inhibitors, and DNA crosslinking agents. The most common ones are by far DNA-damaging agents that generally destroy cancer cells by inducing apoptosis (Barry et al., 1990; Schmitt and Lowe, 1999; Kaufmann and Earnshaw, 2000) through a p53dependent mechanism (Clarke et al., 1993; Lowe et al., 1993; Li et al., 1998; Hayakawa et al., 2000). In response to DNA damage induced by cytotoxic drugs, p53 protein level and functional activity increase, and thereby induces cell cycle arrest or apoptosis (Kastan et 
al., 1991; Clarke et al., 1993; Tishler et al., 1993; Chernov and Stark, 1997). In general, cells with $p 53$ mutations have been shown to be more resistant to chemotherapy (Fan et al., 1994; Lowe et al., 1994; Nabeya et al., 1995; Righetti et al., 1996).

\subsection{CP-31398 - a p53 stabilizing compound}

\subsubsection{Chemical structure of CP-31398}

In approximately $50 \%$ of all human tumours, p53 tumour suppressor gene can be inactivated by a single point mutation. Such a high mutation frequency indicates a strong selection for loss of normal p53 function during tumourigenesis. Foster and colleagues (Foster et al., 1999) screened a library of 100,000 synthetic compounds in order to identify small molecules that can rescue mutant p53 and could stabilize the native conformation of the wild-type p53 core domain upon thermal denaturation. Samples were heated in the presence of compounds and $\mathrm{p} 53$ conformation was assessed by the conformation-specific antibodies PAb1620 and PAb240 that recognize the folded and unfolded conformations of $\mathrm{p} 53$, respectively.

The most promising molecule, CP-31398 is a compound that consists of a polycyclic hydrophobic group (R1) joined to an ionizable group (R2, usually an amine) by a linker of a specific length (Figure 1.2). The R1 and R2 groups of the active compounds are believed to make bivalent contact with the $\mathrm{p} 53$ protein at two adjacent sites. The linker orients these two groups on the $\mathrm{p} 53$ protein to enhance the stability of the active conformation (Foster et al., 1999). 
FIGURE 1.2 Chemical structure of p53-stabilizing compound, CP-31398. The compound consists of a hydrophobic group (R1, polycyclic) joined to an ionizable group (R2, often an amine) by a propyl-length linker.

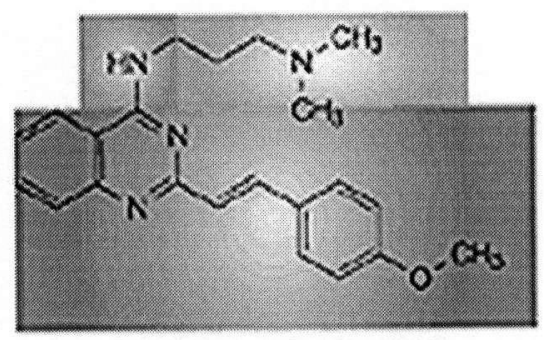

口R1 $\square R 2 \quad \square$ Linker 


\subsubsection{Interaction between CP-31398 and cellular proteins}

CP-31398 enhanced the stability of Ala-173 and His-273 mutant p53 core domains in vitro, restored native conformation and transcriptional transactivation activity to Ala-173 mutant p53 in living cells, and caused the induction of the p53 target gene p21 ${ }^{\text {Wafl }}$. Moreover, CP-31398 inhibited the growth of human melanoma and colon carcinoma cells carrying mutated p53 at position 249 or 241 , respectively, in nude mice. No toxicity was observed at the therapeutic doses in vivo by the first report on this compound (Foster et al., 1999).

At present, the exact mechanism of $\mathrm{CP}-31398$ remains controversial. The compound could interact directly with already synthesized p53 or mediate p53 folding during biosynthesis. The first attempt to detect physical interactions between $\mathrm{p} 53$ and CP31398 was unsuccessful. NMR did not show that CP-31398 binds to the core DNA binding domain of either recombinant wild-type or mutant p53. Rather, gel shift assays and NMR indicated that the compound binds DNA. Some experimental evidence suggests that CP-31398 can affect the folding of newly synthesized p53 only, which could explain the negative NMR results (Rippin et al., 2002).

Further studies confirmed that CP-31398 treatment causes the induction of p53 target genes like p21 ${ }^{\text {Wafl }}$, Mdm2, Bax and Killer/DR5 (Takimoto et al., 2002). CP-31398 also induced apoptosis in HCT116 cells carrying wild-type p53, but not in the isogenic p53-null line in which wild-type p53 has been knocked out. The compound caused an increased wild-type p53 levels and activated some p53 target genes such as $\mathrm{p} 21^{\text {Wafl }}$ and Bax in HCT116 cells, but p21 ${ }^{\text {Waff }}$ upreguation was observed to a lesser extent in p53-null HCT116 cells (Luu et al., 2002). 
In support of the initial study, another group found that CP-31398 restored the DNA binding activity of mutant p53 (Takimoto et al., 2002). CP-31398 upregulated and stabilized p53 protein levels in wild-type p53 expressing cell lines. It also induced apoptosis in six out of nine cell lines, with two of them also experienced $G_{1}$ cell cycle arrest.

CP-31398-mediated upregulation of wild-type p53 levels and transcativation of downstream p53 targets could simply because of the induction of DNA damage, as NMR studies have indicated that the compound is a DNA intercalator. Yet, p53 phosphorylation at Ser-15 and Ser-20, which is often associated with DNA damage, has not been observed after treatment with CP-31398 (Wang et al., 2003). Instead, they showed that CP-31398 inhibited the ubiquitination of wild-type p53, which may explain its ability to induce p53 accumulation. Since a solid conclusion cannot be drawn from previous studies, more work is essential to further explore the possibility of this compound as a therapeutic agent. 


\section{CHAPTER 2. MATERIALS AND METHODS}

\subsection{Materials}

\subsubsection{Cell lines and cell culture}

Three human melanoma cell lines with known p53 status were used for this study. The MMRU cell line was a kind gift from Dr. H.R. Byers (Boston University School of Medicine, Boston, MA) (Byers et al., 1991); the MeWo and Sk-mel-110 cell lines were kind gifts of Dr. A.P. Albino (Memorial Sloan-Kettering Cancer Centre, New York, NY). The $p 53$ status in these melanoma cell lines has been determined by DNA sequencing: MMRU contain wild-type $p 53$ (Li et al., 1995), while MeWo and Sk-mel-110 contain mutant p53 (Albino et al., 1994). Melanoma cell lines were maintained in Dulbecco's Modified Eagle Medium (DMEM) supplemented with 10\% fetal bovine serum (Invitrogen, Burlington, $\mathrm{ON}$ ), $100 \mathrm{U} \mathrm{mL}^{-1}$ penicillin, and $100 \mu \mathrm{g} \mathrm{mL} \mathrm{L}^{-1}$ streptomycin at $37^{\circ} \mathrm{C}$ (in a humidified atmosphere of $5 \%$ carbon dioxide.

\subsubsection{Reagents, enzymes, and chemicals}

Proteinase $\mathrm{K}$ and agarose were obtained from Invitrogen. The CP-31398 compound (Pfizer, Groton, CT) was dissolved in deionized distilled water $\left(\mathrm{ddH}_{2} \mathrm{O}\right)$, filtered and stored at $4^{\circ} \mathrm{C}$. All other chemicals were purchased from Sigma-Aldrich (Mississauga, ON). 


\subsection{Methods}

\subsubsection{Cell survival assay}

Melanoma cells were seeded in 24-well plates at $4 \times 10^{5}$ cells per well and treated with CP31398 at $80 \%$ confluency. Cell survival was determined with sulforhodamine B (SRB) (Sigma-Aldrich, Mississauga, ON, Canada) assay as described previously (Skehan et al., 1990). SRB is a pink aminoxanthene dye with two sulfonic groups that binds to basic amino acid residues of proteins in cells fixed with trichloroacetate (TCA). This assay can provide a sensitive index of cellular protein content that is suitable for screening the number of adhering cells. After treating cells with CP-31398, growth medium was removed from each well and cells were fixed with $500 \mu \mathrm{L}$ of $10 \%$ TCA for $1 \mathrm{~h}$ at $4^{\circ} \mathrm{C}$. Cells were then washed with distilled water for five times and excess water was removed. After air-dried overnight, cells were stained with $500 \mu \mathrm{L}$ of $0.4 \%$ SRB (w/v in $1 \%$ acetic acid) for $30 \mathrm{~min}$ at room temperature followed by four times of $1 \%$ acetic acid washes. Excess acetic acid was removed and cells were air-dried overnight. To solubilize the bound dye, $500 \mu \mathrm{L}$ of $10 \mathrm{mM}$ Tris (pH 10.5) was added to each well. Following $20 \mathrm{~min}$ on a shaker, spectrophotometric readings were obtained at $550 \mathrm{~nm}$ for $100 \mu \mathrm{L}$ aliquot from each well.

\subsubsection{Propidium iodide staining}

Melanoma cells were seeded in 24-well plates at $4 \times 10^{5}$ cells per well and treated with $\mathrm{CP}-$ 31398 at $80 \%$ confluency. Immediately after the treatment, cells pellets were collected by trypsinization followed by centrifugation at $2,000 \mathrm{~g}$ for $5 \mathrm{~min}$. Cell pellets were then resuspended in $1 \mathrm{~mL}$ of hypotonic fluorochrome buffer $(0.1 \%$ Triton $\mathrm{X}-100,0.1 \%$ Sodium 
citrate, $25 \mu \mathrm{g} \mathrm{mL}^{-1} \mathrm{RNase} \mathrm{A}$, and $50 \mu \mathrm{g} \mathrm{mL}^{-1}$ propidium iodide). Cells were then incubated at $4^{\circ} \mathrm{C}$ for $1 \mathrm{~h}$, examined by a Coulter EPICS XL-MCL flow cytometer (Beckman Coulter, Mississauga, ON) and analyzed with EXPO32 ADC analysis software to determine the percentage of cells that consist of different amount of DNA. Stained cells were also visualized under a fluorescent microscope (Zeiss, Chester, VA). Fluorescent microscopic images were taken with a cooled mono 12-bit Retiga-Ex camera (Q-imaging, Burnaby, BC, Canada) using the Northern Eclipse microscopy image analysis software (Empix Imaging, Mississauga, ON, Canada).

\subsubsection{DNA fragmentation assay}

Melanoma cells were grown in 100-mm plates and treated with CP-31398 at $80 \%$ confluency. Cells were collected and the number of cells was equalized after each treatment. Harvested cells were resuspended in $500 \mu \mathrm{L}$ of proteinase $\mathrm{K}$ lysis buffer (20 $\mathrm{mM}$ calcium chloride, $0.5 \%$ SDS, $10 \mathrm{mM}$ Tris- $\mathrm{HCl}$, and $5 \mathrm{mM}$ EDTA at $\mathrm{pH} 8.0$ ) containing $1 \mathrm{mg} \mathrm{mL} L^{-1}$ proteinase $\mathrm{K}$ (Invitrogen,) and incubated at $54^{\circ} \mathrm{C}$ with gentle agitation for $2 \mathrm{~h}$. DNA was then extracted with phenol:chloroform (Sigma-Aldrich), ethanol precipitated, and resuspended at $37^{\circ} \mathrm{C}$ for $30 \mathrm{~min}$ in $20 \mu \mathrm{L}$ of elution buffer (10 $\mathrm{mM}$ Tris- $\mathrm{HCl}$ and $0.5 \mathrm{mM}$ EDTA [pH 9.0]). DNA was then analyzed on a $2 \%$ agarose gel for DNA fragmentation. The gels were stained with $0.5 \mu \mathrm{g} \mathrm{mL}^{-1}$ of ethidium bromide and photographed under UV light with the gel print system (Biophotonics, Ann Arbor, MI). 


\subsubsection{Immunofluorescent staining}

Melanoma cells were grown on glass coverslips in $35-\mathrm{mm}$ plates and treated with CP31398 at $80 \%$ confluency. Immediately after treatment, cells were washed twice with phosphate buffered saline (PBS) for $30 \mathrm{~s}$ each followed by $10 \mathrm{~min}$ of fixation and extraction with $2 \mathrm{~mL}$ of Fix/ex solution (8\% paraformaldehyde, $4 \%$ sucrose in PBS [pH 7.2]) at room temperature. Cells were then washed three times 5 min each with PBS. In order to eliminate free aldehyde groups, cells were incubated with $1 \mathrm{mg} \mathrm{mL}^{-1}$ of sodium borohydride $\left(\mathrm{NaBH}_{4}\right)$ in PBS three times 5 min each. Fixed cells on coverslips were then inverted onto $50 \mu \mathrm{L}$ of 1:25 dilution of p53 antibody DO-1 (Santa Cruz Biotechnology, Santa Cruz, CA) or PAb1620 (Oncogene, Boston, MA) in a humidifying chamber for $1 \mathrm{~h}$. Cells were washed three times $5 \mathrm{~min}$ each with PBS. Subsequently, cells were incubated in $50 \mu \mathrm{L}$ of secondary antibody at 1:100 dilution for $1 \mathrm{~h}$ followed by three washes with PBS for 5 min each. Cells were counter-stained with Hoescht 33258 before fixing on coverslips and mounting onto slides with Permount (Fisher Scientific, Nepean, ON, Canada) and visualized under a fluorescent microscope.

\subsubsection{Mitochondrial transmembrane potential detection (MitoCapture ${ }^{\mathrm{TM}}$ )}

The MitoCapture ${ }^{\mathrm{TM}}$ Apoptosis Detection Kit (Calbiochem, San Diego, CA) provides a fluorescent-based method for distinguishing the healthy and apoptotic cells by detecting the changes in the mitochondrial membrane potential. The assay was performed according to the manufacturer's specifications. Melanoma cells were grown in 35-mm plates and treated with CP-31398 at $80 \%$ confluency. Following the drug treatment, $1 \times 10^{6}$ cells per sample was resuspended in $1 \mathrm{~mL}$ of diluted MitoCapture ${ }^{\mathrm{TM}}$ cationic dye and incubated in a 
$5 \% \mathrm{CO}_{2}$ incubator at $37^{\circ} \mathrm{C}$ for $20 \mathrm{~min}$. Cells were then centrifuged at $500 \mathrm{~g}$ for $5 \mathrm{~min}$ and the cell pellets were resuspended in $1 \mathrm{~mL}$ of pre-warmed incubation buffer. Immediately afterwards, melanoma cells were observed under a fluorescence microscope. MitoCapture $^{\mathrm{TM}}$ reagent that was aggregated in the mitochondria of healthy cells generates a red fluorescence. In apoptotic cells, MitoCapture reagent cannot accumulate in the mitochondria and remains in the cytoplasm, generating a green fluorescence.

\subsubsection{Western blot analysis}

Melanoma cells were grown in $100-\mathrm{mm}$ plates and treated at $80 \%$ confluency. Immediately after treatment, cells were harvested and subjected to Western blot analysis as described (Towbin et al., 1979; Burnette, 1981). Briefly, cells were harvested and lysed on ice for $10 \mathrm{~min}$ with $50 \mu \mathrm{L}$ of Lysis buffer [1.0\% NP-40, $0.5 \%$ sodium deoxycholate, 150 $\mathrm{mM}$ sodium chloride, and $50 \mathrm{mM}$ HEPES ( $\mathrm{pH} 7.5)$ ] containing a mixture of freshly prepared protease inhibitors $\left(100 \mu \mathrm{g} \mathrm{m}^{-1}\right.$ phenylmethylsulfonyl fluoride, $1 \mu \mathrm{g} \mathrm{mL} \mathrm{m}^{-1}$ aprotinin, $1 \mu \mathrm{g} \mathrm{mL}^{-1}$ leupeptin, and $1 \mu \mathrm{g} \mathrm{mL}^{-1}$ pepstatin A). Cell pellets were obtained by spinning at $16,000 \mathrm{~g}$ in an Eppendorf microfuge for $10 \mathrm{~min}$ at $4^{\circ} \mathrm{C}$. Supernatant was then transferred to a new tube and the pellet was discarded. The protein concentration was determined using Bradford assay (Bio-Rad, Mississauga, ON, Canada) at A 280. $50 \mu \mathrm{g}$ per lane of protein was separated by either $8 \%$ or $12 \%$ SDS-PAGE and blotted onto polyvinylidene difluoride (PVDF) membranes. PVDF membranes were immersed in blocking buffer $[5.0 \%$ bovine serum albumin (BSA), $0.05 \%$ Tween 20 , and Tris buffered saline (TBS) (pH 7.2)] blocked overnight. Membrane was then incubated with primary antibody diluted in TBS with $5.0 \% \mathrm{BSA}$ for $60 \mathrm{~min}$ at room temperature. After three times 
ten min each of washing in TBS with $0.05 \%$ Tween 20 , membrane was incubated with horseradish peroxidase (HRP)-conjugated secondary antibody for $45 \mathrm{~min}$ at room temperature. After another three times ten min each of washing in TBS with $0.05 \%$ Tween 20, signals were detected with enhanced chemiluminescence detection kit (Amersham Biosciences, Baie d'Urfe, QC, Canada). Protein expressions on Western blots were quantified by densitometry with Quantity One software (Bio-Rad, Mississauga, ON, Canada). The fold-induction or reduction was corrected for differences in the actin loading control. Antibodies used for Western blotting were p53 (DO-1) (Santa Cruz Biotechnology, Santa Cruz, CA), caspase-3, Apaf-1, $\beta$-actin (BD Pharmingen, Missisauga, ON, Canada), and caspase-9 (Calbiochem, SanDiego, CA)

\subsubsection{Subcellular fractionation}

Melanoma cells were grown in 100-mm plates, treated with CP-31398 at $80 \%$ confluency, and the subcellular fractionation was performed as described previously (Kim et al., 2001) with minor modifications. Treated cells were harvested on ice and resuspended in $500 \mu \mathrm{L}$ buffer A (20 mM HEPES-KOH [pH 7.5], $10 \mathrm{mM} \mathrm{KCl}, 1.5 \mathrm{mM} \mathrm{MgCl} 2,1 \mathrm{mM}$ sodium EDTA, $1 \mathrm{mM}$ sodium EGTA, $1 \mathrm{mM}$ dithiothreitol, and $250 \mathrm{mM}$ sucrose) containing a mixture of freshly prepared protease inhibitors $\left(100 \mu \mathrm{g} \mathrm{mL}^{-1}\right.$ phenylmethylsulfonyl fluoride, $1 \mu \mathrm{g} \mathrm{mL} L^{-1}$ aprotinin, $1 \mu \mathrm{g} \mathrm{mL}^{-1}$ leupeptin, and $1 \mu \mathrm{g} \mathrm{mL} L^{-1}$ pepstatin A). Resuspended cells were then passed through a 26-gauge needle 10 times to lyse cells. Unbroken cells, large fractured plasma membrane, and nuclei were removed by centrifugation at $1,000 \mathrm{~g}$ at $4^{\circ} \mathrm{C}$ for $10 \mathrm{~min}$. The resulting supernatant was then further centrifuged at $10,000 \mathrm{~g}$ at $4^{\circ} \mathrm{C}$ for $20 \mathrm{~min}$. The pelleted mitochondrial fraction was washed 
with buffer A once and then solubilized in $50 \mu \mathrm{L}$ of TNC buffer $(10 \mathrm{mM}$ Tris-acetate, $0.5 \% \mathrm{NP}-40$, and $5 \mathrm{mM} \mathrm{CaCl}_{2}$ ) containing a mixture of freshly prepared protease inhibitors as described above. The cytosol fraction was generated by centrifugation of the supernatant at $100,000 \mathrm{~g}$ at $4^{\circ} \mathrm{C}$ for $60 \mathrm{~min}$. The protein concentration was determined using Bradford assay (Bio-Rad). $50 \mu \mathrm{g}$ per lane of protein was separated by $15 \%$ SDS-PAGE and blotted onto polyvinylidene difluoride (PVDF) membranes. After overnight blocking with the blocking buffer (5.0\% bovine serum albumin, $0.05 \%$ Tween 20 , and Tris buffered saline (TBS) [pH 7.2]), PVDF membranes were probed with anti-cytochrome $c$ (BD Pharmingen) antibodies and detected with enhanced chemiluminescence detection kit (Amersham Biosciences).

\subsubsection{Reverse transcriptase-polymerase chain reaction (RT-PCR)}

Melanoma cells were grown in 100-mm plates and treated with CP-31398 at 80\% confluency, followed by total RNA extraction according to the manufacturer's specifications using the TRIzol ${ }^{\mathrm{TM}}$ Reagent (Invitrogen). Extracted RNA was quantified by UV spectrophotometry (Pharmacia Biotech, Cambridge, England). First-strand cDNA was prepared from $3 \mu \mathrm{g}$ of total RNA reverse-transcribed into cDNA using the Omniscript RTkit (Qiagen Inc., Mississauga, ON, Canada). A mix containing 10x RT buffer, $5 \mathrm{mM}$ dNTP mix and $10 \mu \mathrm{M}$ of oligo-dT primer (Invitrogen) to a total volume of $20 \mu \mathrm{L}$. The RT mix was incubated at $37^{\circ} \mathrm{C}$ for $60 \mathrm{~min}$ followed by an inactivation at $93^{\circ} \mathrm{C}$ for $5 \mathrm{~min}$.

For semi-quantitative PCR, $2 \mu \mathrm{L}$ of the first strand reaction were used for the total volume of $25 \mu \mathrm{L}$ PCR reaction. Each reaction contained 10× PCR buffer (200 mM Tris- 
$\mathrm{HCl}[\mathrm{pH} 8.4], 500 \mathrm{mM} \mathrm{KCl}, 50 \mathrm{mM} \mathrm{MgCl} 2,10 \mathrm{mM}$ dNTP mix, $25 \mu \mathrm{M}$ of specific primers, and $5 \mathrm{U} \mu \mathrm{L}^{-1}$ of Taq DNA ploymerase) (Qiagen).

Specific primers are as followed:

Bax forward, 5'-AGCGGCGGTGAT GGACGGGTC-3',

Bax reverse, 5'-TCCAAGGCAGCTGGGGCCTCA-3' (608 bp);

$p 21^{\text {Wafl }}$ forward, 5'-ATGTCAGAACCGGCTGGG-3',

p21 $1^{\text {Wafl }}$ reverse, 5'-TTAGGGCTTCCTCTTGGA-3' (477 bp);

PUMA forward, 5'-TGTAGAGGAGACAGGAATCCACGG-3',

PUMA reverse, 5'-AGGCACCTAATTGGGCTCCATCTC-3' (311 bp);

GAPDH forward, 5'-CCACCCATGGCAAATTCCATGGCA-3',

GAPDH reverse, 5'-TCTAGACGGCAGGTCAGGTCCACC-3' (270 bp).

The PCR mix was amplified as follows: 1) initial denaturation at $95^{\circ} \mathrm{C}$ for $3 \mathrm{~min}, 2$ ) denaturation at $95^{\circ} \mathrm{C}$ for $\left.1 \mathrm{~min}, 3\right)$ annealing at $52^{\circ} \mathrm{C}(G A P D H), 55^{\circ} \mathrm{C}\left(p 21^{\text {Wafl }}\right)$, or $58^{\circ} \mathrm{C}$ (Bax and $P U M A$ ) for $30 \mathrm{~s}, 4)$ polymerization at $72^{\circ} \mathrm{C}$ for $30 \mathrm{~s}, 5$ ) repeat steps two to four for the indicated number of cycles (30 for GAPDH and $p 21^{\text {Wafl }}$, or 35 cycles for Bax and PUMA), and 6) final extension and polymerization at $72^{\circ} \mathrm{C}$ for $3 \mathrm{~min}$. Samples were then electrophoresed on $2 \%$ agarose gels containing $0.5 \mu \mathrm{g} \mathrm{mL}{ }^{-1}$ ethidium bromide, visualized under UV light and photographed with the gel print system. The levels of mRNA expression were quantified by densitometry using the Quantity One software (Bio-Rad). The fold-induction was corrected for differences in the GAPDH internal loading control. 


\section{CHAPTER 3. DIFFERENTIAL RESPONSES OF MELANOMA CELL LINES WITH VARIOUS P53}

MUTATIONAL STATUSES TO CP-31398-INDUCED

\section{APOPTOSIS}

\subsection{Rationale and Hypothesis}

Metastatic melanoma is one of the most aggressive cancers with its death rate continuing to climb. Although surgical excision or tumours might provide some benefit by alleviating pain and enhancing the quality of life, advanced melanoma that has spread to internal organs often cannot be cured. Currently, the only treatment option for metastatic melanoma is chemotherapy but the response rate is very low because of resistant to conventional drugs (Garbe, 1993; Helmbach et al., 2001). The exact resistance mechanisms vary depending on the mechanistic action of different drugs.

In some drug-resistant cancer cell lines, the level of intracellular level of drugs is reduced because of an increased efflux by P-glycoprotein (P-gp) (Gottesman and Pastan, 1993). This might be essential because in order for an anticancer drug to have an effect on cancer cells, a significant concentration must be reached inside a cell. In primary and metatstatic melanoma, as well as in melanoma cell lines, however, no significant melanoma-specific correlation can be drawn between P-gp expression level and response to chemotherapy in melanoma patients (Schadendorf et al., 1995). As a result, P-gp is not considered as a major drug resistance mediator in human melanoma cells. 
Some anticancer agents, such as etoposide, target topoisomerase after entering a cell. Topoisomerase is a nuclear enzyme that participates in DNA transcription and recombination during mitosis. In fact, increased activity of topoisomerase II has been shown to correlate with etoposide resistance in melanoma (Lage et al., 2000).

Other chemotherapeutic agents, such as cisplatin, act through induction of apoptosis. Their reduced efficiency in melanoma probably relates to defective apoptotic machinery when compared to other malignant cell types (Kaufmann and Earnshaw, 2000). Furthermore, the ability of anticancer agents to trigger caspase activation appears to be a critical determinant of sensitivity or resistance to cytotoxic therapies. Thus, inhibition of caspase activation may be an important factor in chemoresistance.

p53 is a widely-studied tumour suppressor that has the ability to trigger cell-cycle arrest and apoptosis in response to diverse stress stimuli. Under cellular stress, such as hypoxia, DNA damage, ionizing radiation, exposure to anticancer drugs, and oncogene activation, the p53 protein is rapidly accumulated in a cell (Ko and Prives, 1996; Giaccia and Kastan, 1998; Sherr, 1998; Asker et al., 1999). This increase in p53 protein level can further transactivate its downstream target genes through specific DNA binding. Depending on the extent of DNA damage, $\mathrm{p} 53$ can either bring about cell cycle arrest in an effort to repair the damage, or induce apoptosis when the damage is too severe (Li et al., 1997a; Tron et al., 1998a). Apoptosis, or programmed cell death, is a tightly regulated self-protective mechanism in order to eliminate unnecessary or severely damaged cells.

More than half of all human tumours contain $p 53$ mutations and majority of the mutations are located in the DNA binding domain (Beroud and Soussi, 1998). The prevalent disruption of the specific DNA binding function of p53 by gene mutation 
suggests that this function is critical for p53-mediated tumour suppression. Many conventional chemotherapeutic agents exploit this p53-dependent apoptotic pathway through DNA damaging events to destroy cancerous cells (Li et al., 2000). In fact, tumours carrying mutant $p 53$ are often more resistant to chemotherapy than those carrying wild-type p53 (Levine, 1997). Additionally, studies using the more complicated genetic background of tumour-derived cell lines found a high dependency of most clinically established anticancer drugs on functional p53 (Lowe et al., 1994; Lowe, 1995; Weinstein et al., 1997).

Conventional therapeutic agents amplify stress signals impelling damaged cells to self-destruct. Unfortunately, treatment fails when the cancer inactivates tumour-suppressor pathways. In most malignancies, mutation in $p 53$ leads to a shut down of the p53 tumour suppressor signaling pathway (Bullock and Fersht, 2001). Various strategies have been explored to restore mutant p53 to wild-type function (Selivanova et al., 1998). A class of small pharmacological compounds has been identified in a random screening of over 100,000 synthetic molecules for its ability to promote the stable active conformation of wild-type p53. This class of small-molecule compounds can increase the activity of p53 and induce apoptosis in tumour cells (Foster et al., 1999). Among all, CP-31398 showed the strongest ability to stabilize the wild-type $\mathrm{p} 53$ protein conformation against thermal denaturation. It was further shown that CP-31398 has a remarkable capacity to restore mutant p53 to behave like wild-type p53 and induce apoptosis in a number of cancer cell lines including melanoma cells (Foster et al., 1999; Luu et al., 2002; Rippin et al., 2002; Takimoto et al., 2002). Indeed, tumour cells are likely to be particularly sensitive to p53 reactivation. Some mutant $\mathrm{p} 53$ proteins tend to accumulate at high levels in tumour cells, 
mainly due to inability of mutant $\mathrm{p} 53$ to transactivate $\mathrm{Mdm} 2$, whose product induces $\mathrm{p} 53$ degradation. Thus, reactivation of abundant mutant p53 may trigger a massive apoptotic response in tumour cells, whereas normal cells that express minute levels of $\mathrm{p} 53$ should not be affected (Bykov et al., 2002).

While Foster and colleagues (1999) claimed that CP-31398 has the ability to rescue all mutant p53 to wild-type p53 activity, Tanner and Barberis (2004) argued that CP-31398 could not stimulate any mutant p53 to restore any detectable p53 activity. These contradictory results prompted us to further look into the apoptotic events caused by $\mathrm{CP}$ 31398. Moreover, seeing that Tanner and Barberis (2004) focused only on the transcription level of a single p53 response element, $\mathrm{p} 21^{\text {Wafl }}$, through luciferase activity, we further investigated the effect of CP-31398 from the apoptotic machinery perspective. More importantly, as metastatic melanoma responds poorly to traditional treatment methods, we sought to explore the possibility of using this new small molecule drug as a treatment for melanoma cells with various $p 53$ mutation statuses. Noticing a differential response of melanoma cell lines to CP-31398 after initial screening, we hypothesized that the ability of CP-31398 to revert mutant p53 to wild-type p53 conformation may not be universal. 


\subsection{Results}

\subsubsection{Effects of CP-31398 on survival of human melanoma cells}

Three human melanoma cell lines with different $p 53$ statuses were used for all the experiments. MMRU cells carry a wild-type $p 53$ gene while MeWo and Sk-mel-110 cells carry mutant $p 53$ genes (Table 3.1). In order to determine if CP-31398 has the ability to modulate cell survival in all three melanoma cell lines, SRB cell survival assay was performed after CP-31398 treatment. Fig. 3.1 shows the dose-dependent survival rate of melanoma cells after $20 \mathrm{~h}$ of $\mathrm{CP}-31398$ treatment. The $\mathrm{EC}_{50}$ (effective concentration $50 \%$ ) of CP-31398 for MMRU and MeWo was determined to be $15 \mu \mathrm{g} \mathrm{mL}{ }^{-1}$ and this concentration was used for subsequent experiments. Fig. 3.2 shows the time-dependent survival rate of melanoma cell lines with or without $15 \mu \mathrm{g} \mathrm{mL}^{-1}$ of CP-31398 for 0,16 or 24 h. Both MMRU and MeWo cells responded well upon exposure to CP-31398. In MMRU cells, survival rate dropped to $51 \%$ and $30 \%$ after 16 and $24 \mathrm{~h}$ of CP-31398 treatment, respectively $(P<0.05)$. Similar trend was observed in MeWo cells with the survival rate reduced to $53 \%$ and $27 \%$ after 16 and $24 \mathrm{~h}$ of CP-31398 treatment, respectively $(P<0.05)$. In Sk-mel-110, however, survival rate did not change significantly at a moderate concentration. It only decreased to $97 \%$ and $91 \%$ after 16 and $24 \mathrm{~h}$ of CP31398 treatment, respectively. These results indicate that CP-31398 has the ability to modulate the survival rate in some human melanoma cell lines. 
Table 3.1 Description of p53 mutation status found in melanocytic lesions.

\begin{tabular}{ccccccc}
\hline Cell line & p53 status & Exon & Codon & $\begin{array}{c}\text { Nucleotide } \\
\text { substitution }\end{array}$ & $\begin{array}{c}\text { Amino acid } \\
\text { substitution }\end{array}$ & Reference \\
\hline MMRU & Wild type & N/A & N/A & N/A & N/A & (Li et al., 1995) \\
MeWo & Mutant & 10 & 341 & CC $\rightarrow$ TT & phe $\rightarrow$ stop & (Albino et al., 1994) \\
& & 4 & 75 & CCT $\rightarrow$ CCC & pro $\rightarrow$ pro & (Albino et al., 1994) \\
& Mutant & 4 & 76 & GCA $\rightarrow$ ACA & ala $\rightarrow$ thr \\
& & 4 & 104 & CAG $\rightarrow$ CAC & $\begin{array}{l}\text { gln } \rightarrow \text { his } \\
\text { thr } \rightarrow \text { ser }\end{array}$ & \\
& & 5 & 155 & ACC $\rightarrow$ AGC & leu $\rightarrow$ phe & \\
& & 8 & 289 & CTC $\rightarrow$ TTC & his $\rightarrow$ cys & \\
\hline
\end{tabular}

N/A = Not applicable 
Figure 3.1 Survival of human melanoma cells after CP-31398 treatment is dosedependent. Cell survival by SRB assay of MMRU, MeWo and Sk-mel-110 cells treated with various doses of CP-31398 for $20 \mathrm{~h}$. Spectrophotometric readings were obtained and mean values and standard deviations for three independent experiments were calculated.

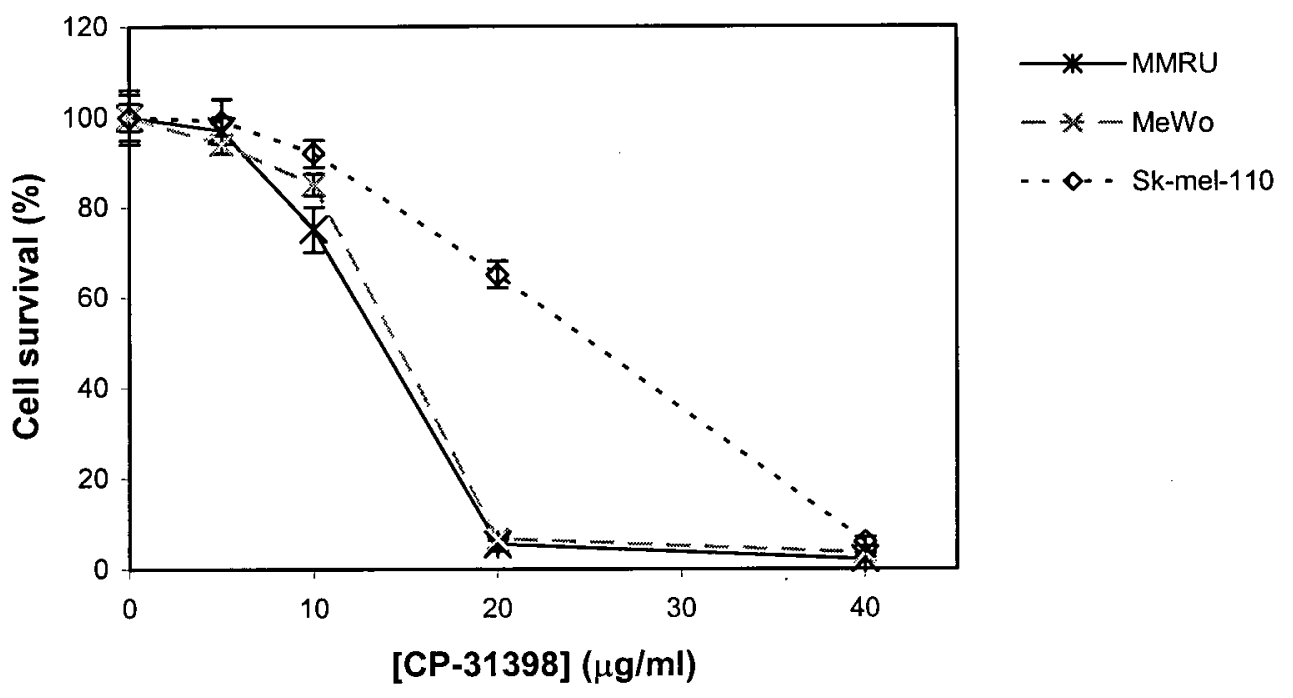


Figure 3.2 Alteration in survival of human melanoma cells after CP-31398 treatment. Cell survival by SRB assay of MMRU, MeWo and Sk-mel-110 cells treated with 0 or 15 $\mu \mathrm{g} \mathrm{mL} \mathrm{L}^{-1}$ of $\mathrm{CP}-31398$ for 16 or $24 \mathrm{~h}$. These experiments were repeated three times with similar results.

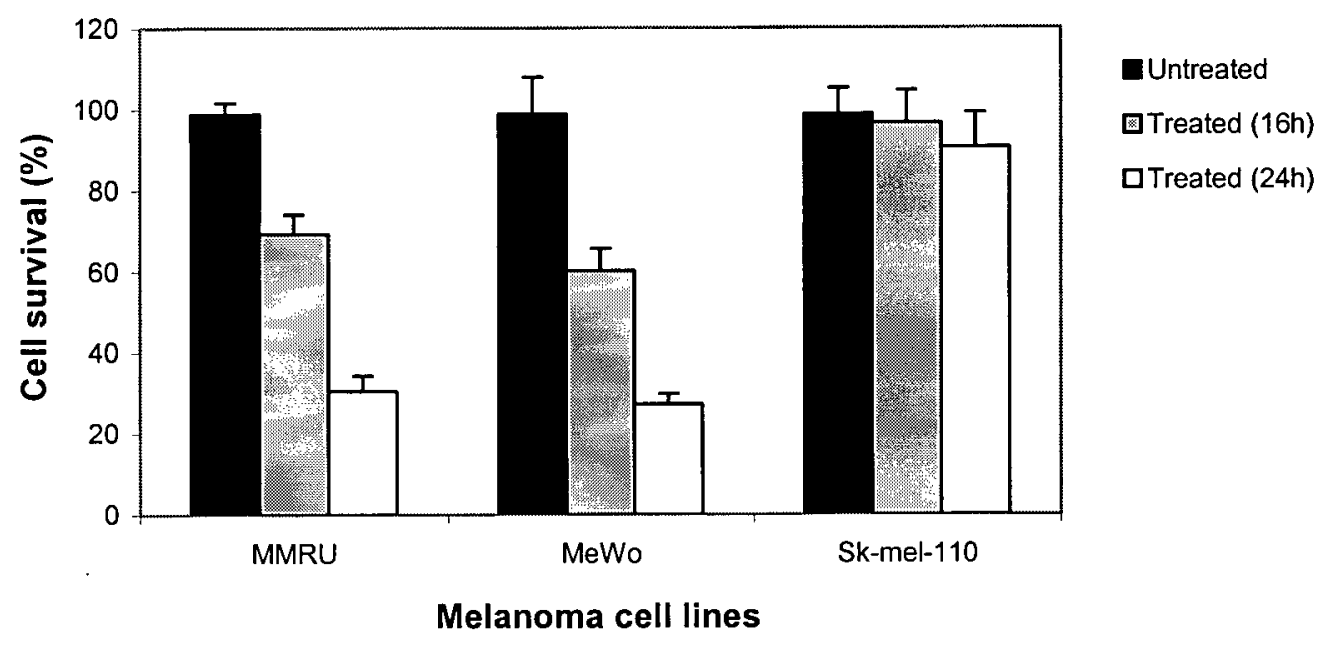




\subsubsection{Differential responses of mutant p53 melanoma cell lines to CP-31398-induced}

\section{apoptosis}

Condensation and fragmentation of DNA is a hallmark of apoptosis. The DNA ladder assay was used to confirm that CP-31398-induced cell death is a result of apoptosis, not necrosis. DNA was extracted from CP-31398-treated cells and analyzed on an agarose gel. Fig. 3.3 shows extensive DNA fragmentation occurs in CP-31398 treated MMRU and MeWo cells but not in Sk-mel-110 cells or the untreated cells. Propidium iodide (PI) staining was also performed on fixed melanoma cells in order to examine the cellular morphological changes after $16 \mathrm{~h}$ of CP-31398 treatment. Arrows in Fig. 3.4 show condensed nucleus and evident apoptotic bodies in CP-31398-treated MMRU and MeWo cells, but not in Sk-mel-110 cells or the untreated control cells.

In addition to the morphological changes as a result of programmed cell death, fragmented hypo-diploid DNA can be visualized as a sub-G $\mathrm{G}_{1}$ peak on a DNA cell cycle histogram (Butt et al., 2000). All melanoma cells with or without CP-31398 treatment were stained with propidium iodide and then analyzed by flow cytometry (Fig. 3.5). An increase of sub- $\mathrm{G}_{1}$ cell percentage in both MMRU and MeWo further confirmed the decreased cell survival observed in SRB assay after CP-31398 treatment (Fig. 3.2). Since CP-31398 has been shown to have the ability to stabilize p53 (Foster et al., 1999), the differential response observed between MMRU, MeWo and Sk-mel-110 cells may well be due to the various mutation statuses of these melanoma cell lines (Table 3.1). 
Figure 3.3 CP-31398 induces DNA fragmentation in human melanoma cells. MMRU, MeWo and Sk-mel-110 cells were treated with 0 or $15 \mu \mathrm{gL}^{-1}$ of CP-31398 for $24 \mathrm{~h}$. DNA was extracted, separated on a $2 \%$ agarose gel, stained with $0.5 \mu \mathrm{g} \mathrm{mL}^{-1}$ of ethidium bromide, and visualized under UV light.

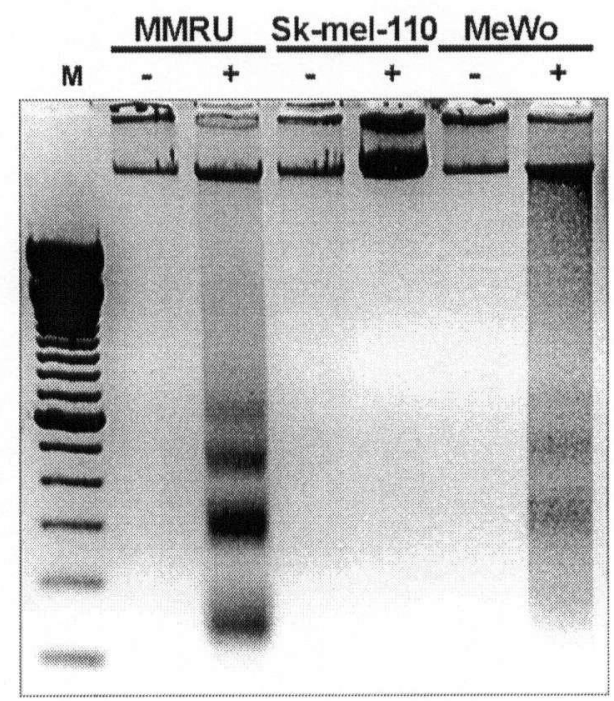


Figure 3.4 CP-31398 induces apoptosis in human melanoma cells. MMRU, MeWo and Sk-mel-110 cells were treated with 0 or $15 \mu \mathrm{g} \mathrm{mL}^{-1}$ of CP-31398 for $16 \mathrm{~h}$, stained with propidium iodide, and visualized under a fluorescent microscope. Arrows indicate apoptotic bodies. Magnification, 200x. These experiments were performed three times with similar results.
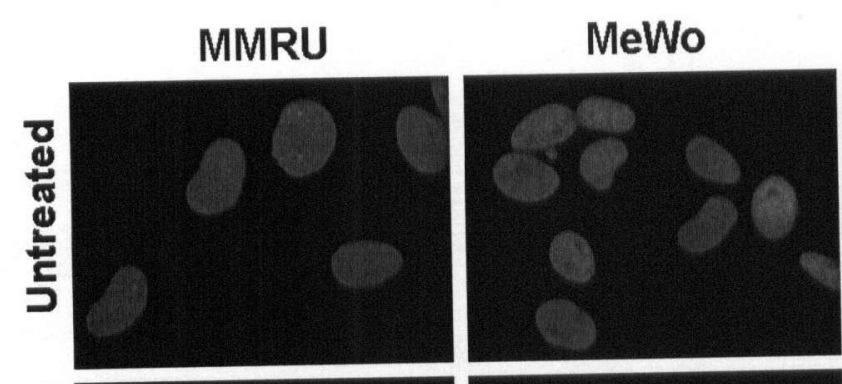

Sk-mel-110
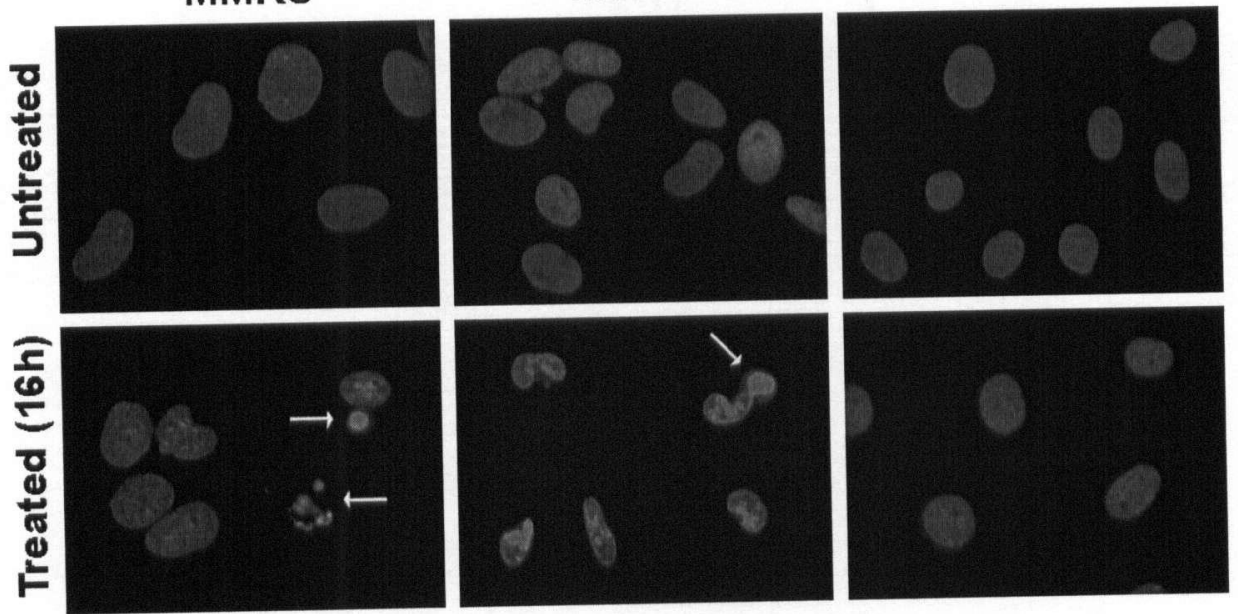
Figure 3.5 CP-31398 increases sub- $\mathrm{G}_{1}$ cell population in human melanoma cells. MMRU, MeWo and Sk-mel-110 cells were treated with 0 or $15 \mu \mathrm{g} \mathrm{mL}^{-1}$ of CP-31398 for 16 or $24 \mathrm{~h}$, stained with propidium iodide, and analyzed by flow cytometry. The experiment was performed three times with similar results and the representative data was shown.

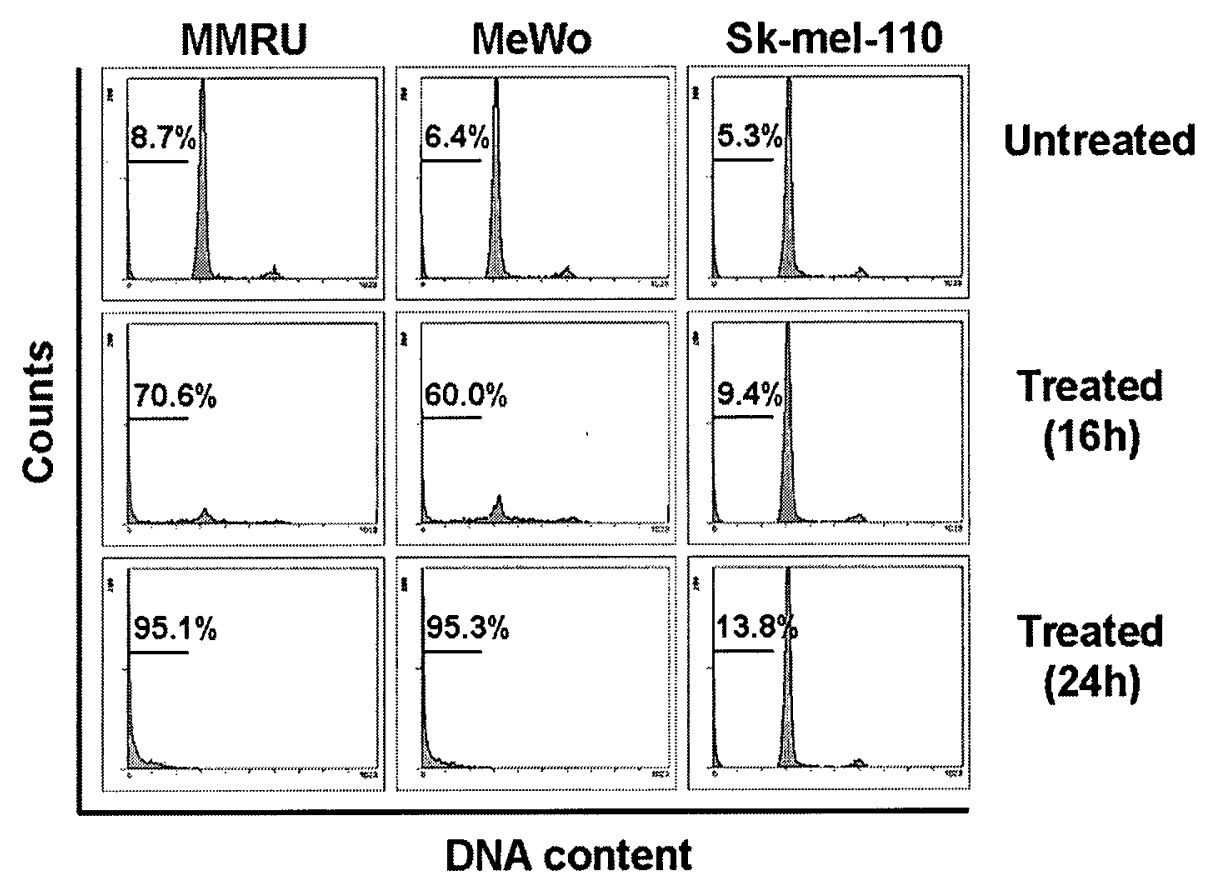




\subsubsection{Restoration and stabilization of $\mathrm{p53}$ wild-type conformation}

Since p53 is involved in apoptosis (Li et al., 1997a; Tron et al., 1998a) and CP-31398 has been shown to have the ability to stabilize p53 (Foster et al., 1999), the level of p53 protein after CP-31398 treatment was examined. With the observed differential response to CP31398 in melanoma cell lines, we performed Western blot analysis to determine if CP31398 treatment affects the level of p53 protein levels. All three melanoma cell lines showed a time-dependent increase in the overall p53 protein levels although MMRU and MeWo cells showed a more significant increase after CP-31398 treatment than nonresponsive Sk-mel-110 cells (Fig. 3.6). Our observation is consistent with the p53 stabilizing effect of this synthetic compound which was shown to block ubiquitination and degradation of p53 as previous described (Foster et al., 1999; Wang et al., 2003).

The level of p53 protein alone may not necessarily correlate to an increased p53 activity because active $\mathrm{p} 53$ conformation must be acquired in order for p53 to function (Hupp et al., 2000). We therefore employed immunofluorescent staining to study the expression level of total and active conformation of p53 protein in vivo. All melanoma cells were immunofluorescent stained $16 \mathrm{~h}$ after $15 \mu \mathrm{g} \mathrm{mL}{ }^{-1} \mathrm{CP}-31398$ treatment and examined under a fluorescent microscope. An upregulation of overall p53 protein levels was detected by a mouse monoclonal anti-p53 antibody DO- 1 in all three melanoma cell lines. DO-1 antibody recognizes both active and inactive conformations of wild-type and mutant p53 (Fig. 3.7) further confirming the results from Western blot analysis (Fig. 3.6). We also used another mouse monoclonal p53 antibody PAb-1620, which is a conformation specific antibody that recognizes the stabilized, non-denatured, active DNA binding domain in p53 protein (Gamble and Milner, 1988; Foster et al., 1999). We showed that 
CP-31398 treatment resulted in a significant increase in the level of active conformation of p53 protein in MMRU and MeWo cells (Fig. 3.7). In contrary, PAb-1620 antibody did not show any positive fluorescence staining in Sk-mel-110 cells. The inability of CP-31398 to rescue mutant p53 into an active and functional p53 in Sk-mel-110 cells may render the resistance to CP-31398-induced apoptosis. 
Figure 3.6 Effect of CP-31398 on the overall expression of p53 proteins in human melanoma cells. Western blot analysis using anti-p53 antibody (DO-1) was performed on proteins extracted from MMRU, MeWo and Sk-mel-110 cells treated with 0 or $15 \mu \mathrm{gL}^{-1}$ of $\mathrm{CP}-31398$ for 0,8 , or $16 \mathrm{~h}$. $\beta$-actin was used as a loading control.

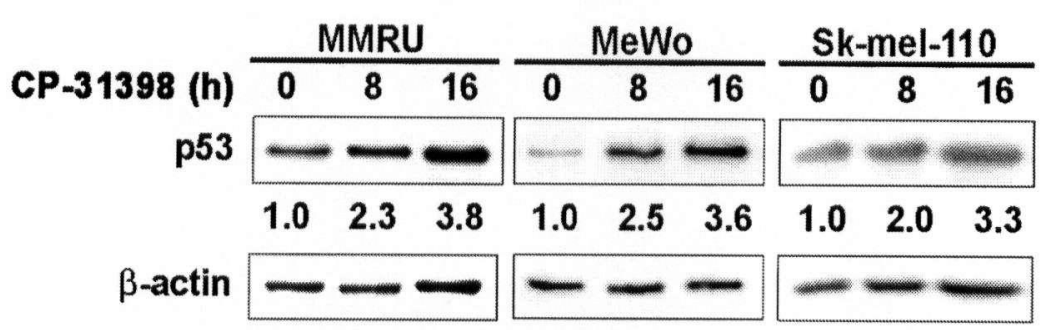


Figure 3.7 Effect of CP-31398 on the expression of $\mathrm{p} 53$ proteins in human melanoma cells. Immunofluorescent staining using anti-p53 antibodies (DO-1 and PAb-1620) was performed on MMRU, MeWo and Sk-mel-110 cells after treated with 0 or $15 \mu \mathrm{g} \mathrm{mL}^{-1}$ of CP-31398 for $16 \mathrm{~h}$. Cells were counter-stained with Hoescht 33248 and overlay on the immunofluorescent pictures. These experiments were performed three times with similar results. Magnification, 200x.

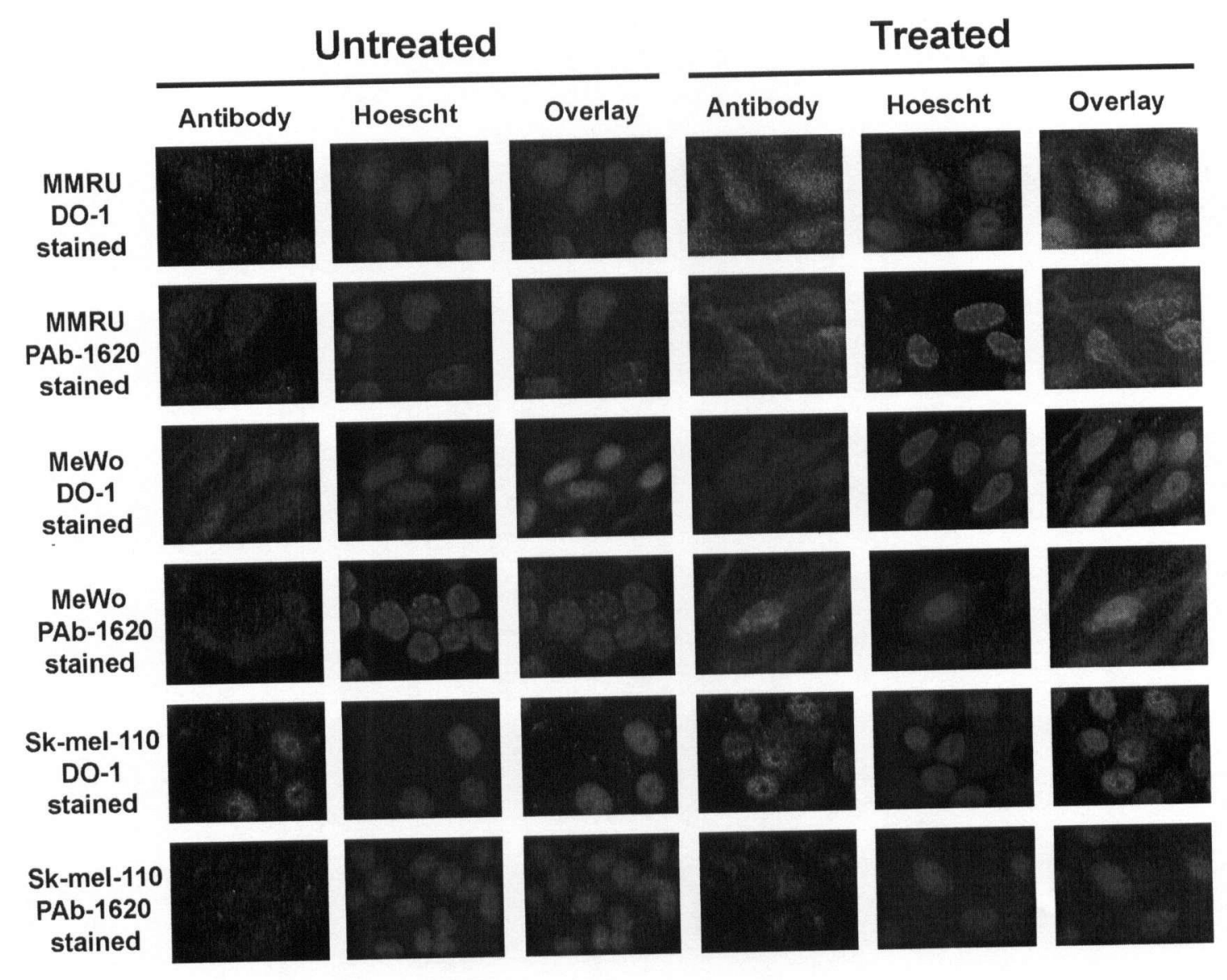




\subsubsection{Activation of p53 transcriptional activity}

To determine if the transcriptional activity of p53 protein is increased after CP31398 treatment, semi-quantitative RT-PCR of several p53 downstream targets was performed. p21 $1^{\text {Wafl }}$ has the ability to inhibit cyclin-kinase activity and is tightly regulated at the transcriptional level by $\mathrm{p} 53$. It serves as an effector of $\mathrm{p} 53$ cell cycle control and mediates $\mathrm{p} 53$ suppression of tumour cell growth. We observed an upregulation of $\mathrm{p} 21^{\text {Wafl }}$ by RT-PCR (Fig. 3.8) after CP-31398 treatment in all melanoma cell lines regardless of the response to CP-31398, which is consistent with the previous observation (Takimoto et al., 2002).

Another $\mathrm{p} 53$ downstream target is Bax, which belongs to the Bcl-2 family apoptotic proteins (Miyashita et al., 1994a; Miyashita et al., 1994b; Miyashita and Reed, 1995). A time-dependent upregulation of Bax mRNA level was observed in both MMRU and MeWo cells when compared to the untreated control (Fig. 3.8). In contrast, Sk-mel-110 cells showed very little difference in Bax expression after CP-31398 treatment, most likely due to the absence of a functional p53 (Wang et al., 1997).

PUMA (p53 upregulated mediator of apoptosis) is a BH3-only mitochondrial protein that is induced in cells following p53 activation. Antisense inhibition of PUMA expression could reduce the apoptotic response to p53, suggesting that PUMA plays an important role in mediating p53-induced cell death in some cell lines (Nakano and Vousden, 2001). We showed a time-dependent increase of PUMA mRNA level in MMRU and MeWo cells (Fig. 3.8). Similar to Bax mRNA level, Sk-mel-110 cells showed very little difference in PUMA mRNA expression after CP-31398 treatment. PUMA protein interacts with other $\mathrm{Bcl}-2$ like proteins and promotes mitochondrial translocation and 
Figure 3.8 Effect of CP-31398 on $\mathrm{p} 21^{\text {Wafl }}$, Bax and PUMA mRNA levels. Semiquantitative RT-PCR of p21 Wafl , Bax and PUMA mRNA level was performed on RNA extracted from MMRU, MeWo and Sk-mel-110 cells treated with 0 or $15 \mu \mathrm{g} \mathrm{mL}^{-1}$ of CP31398 for 0,8 , or $16 \mathrm{~h}$. GAPDH was used as an internal loading control. The experiment was performed three times with similar results and the representative data was shown.

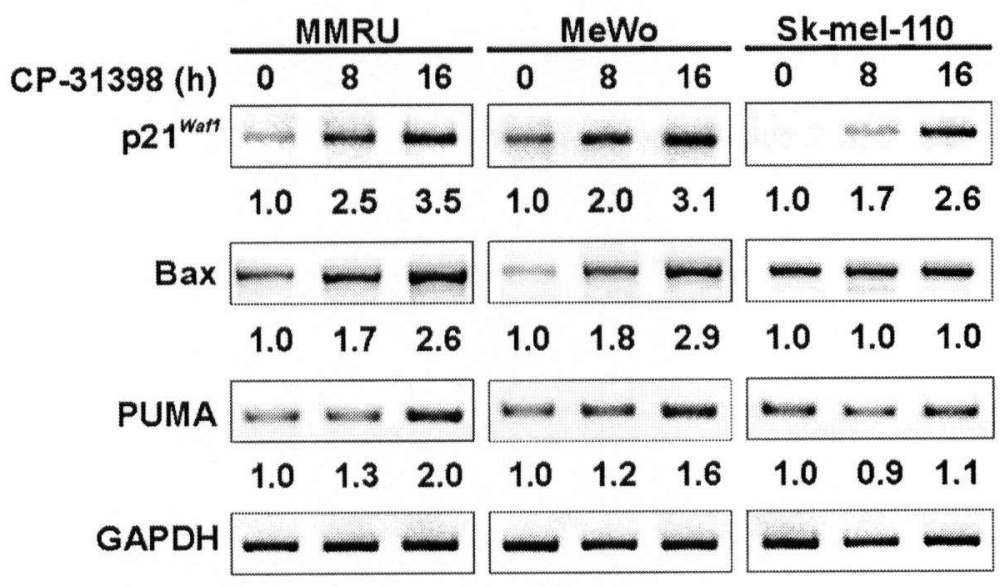


multimerization of Bax (Yu et al., 2003). These results suggested that the increased expression of PUMA and Bax may play a pivotal role in determining the outcome of $\mathrm{p} 53$ dependent apoptosis.

\subsubsection{Alteration of mitochondrial transmembrane potential}

Apoptosis can be caused by many different stimuli, such as cytotoxic drugs and $\gamma$ irradiation. An early stage event in apoptosis is the loss of membrane potential in mitochondria $(\Delta \Psi(\mathrm{M}))$. This change can be regulated by $\mathrm{p} 53$ (Li et al., 1999; Shimizu et al., 1999; Zhang et al., 1999; Karpinich et al., 2002). Furthermore, increased Bax transcription results in mitochondrial membrane permeability change and the release of cytochrome $c$ from the mitochondria into cytosol (Shimizu et al., 1999).

To determine if CP-31398 induces a change in mitochondrial membrane potential during apoptosis, melanoma cells were treated with $15 \mu \mathrm{g} \mathrm{mL}^{-1}$ of CP-31398 for $16 \mathrm{~h}$ and then stained with a cationic dye using the MitoCapture ${ }^{\mathrm{TM}}$ Apoptosis Detection Kit. This cationic dye accumulates and aggregates in the mitochondria in healthy cells and emits a red fluorescence. In apoptotic cells, the dye remains in the cytoplasm due to the change in mitochondrial membrane potential and emits a green fluorescence. These stained cells were visualized under a fluorescent microscope. Fig. 3.9A shows that untreated cells stained red in all three cell lines. After $16 \mathrm{~h}$ of CP-31398 treatment, only CP-31398 sensitive cells MMRU and MeWo showed a green fluorescent staining (apoptotic cells). Fig. 3.9B showed MMRU and MeWo cells had a significantly higher percentage of greenstained apoptotic cells (from $6 \%$ to $95 \%, P<0.005$, and from $6 \%$ to $97 \%, P<0.005$, respectively) than Sk-mel-110 cells after CP-31398 treatment (from 5\% to 7\%). These 
Figure 3.9 Alteration of the mitochondrial membrane potential after CP-31398 treatment. MMRU, MeWo and Sk-mel-110 cells were treated with 0 or $15 \mu \mathrm{g} \mathrm{mL}^{-1}$ of CP31398 for 0 or $16 \mathrm{~h}$, and stained with MitoCapture ${ }^{\mathrm{TM}}$ solution. A) Fluorescent microscopic photographs of control and CP-31398-treated (16 h) MMRU, MeWo and Sk-mel-110 cells. Red fluorescence represents live cells, while green fluorescence specifies apoptotic cells with altered mitochondrial membrane potential. Magnification, 200x. B) Quantification of the percentage of apoptotic cells based on the changes in the mitochondrial membrane potential. At least 500 cells from 5 random fields were counted.

A

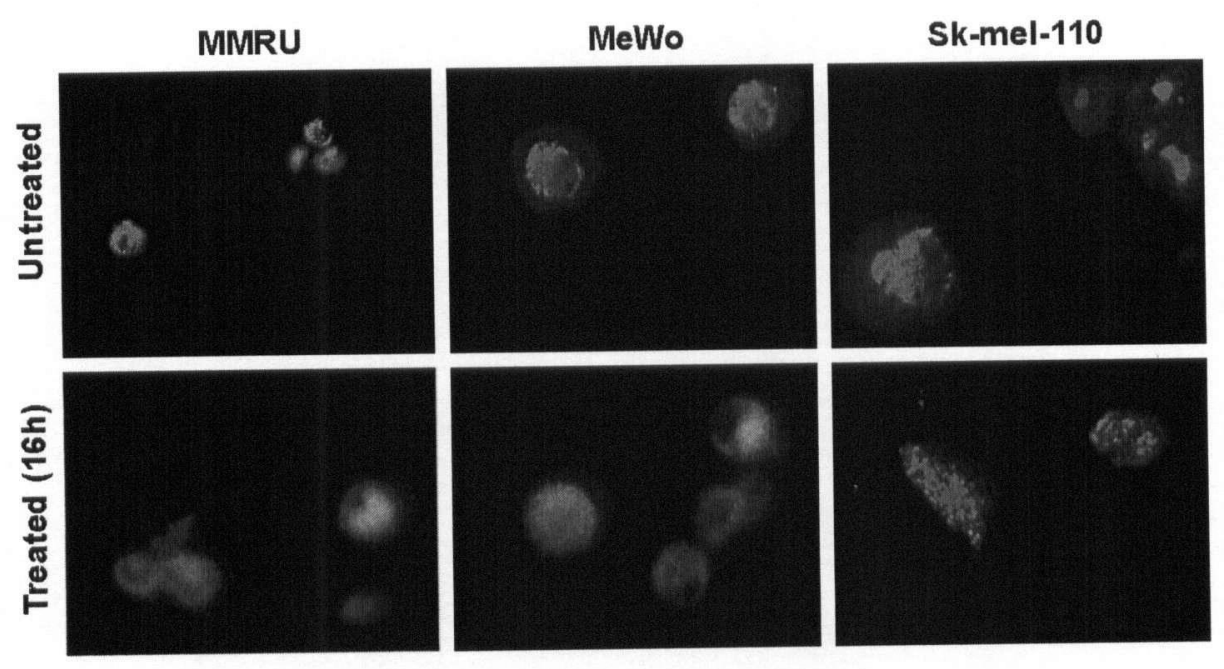

B

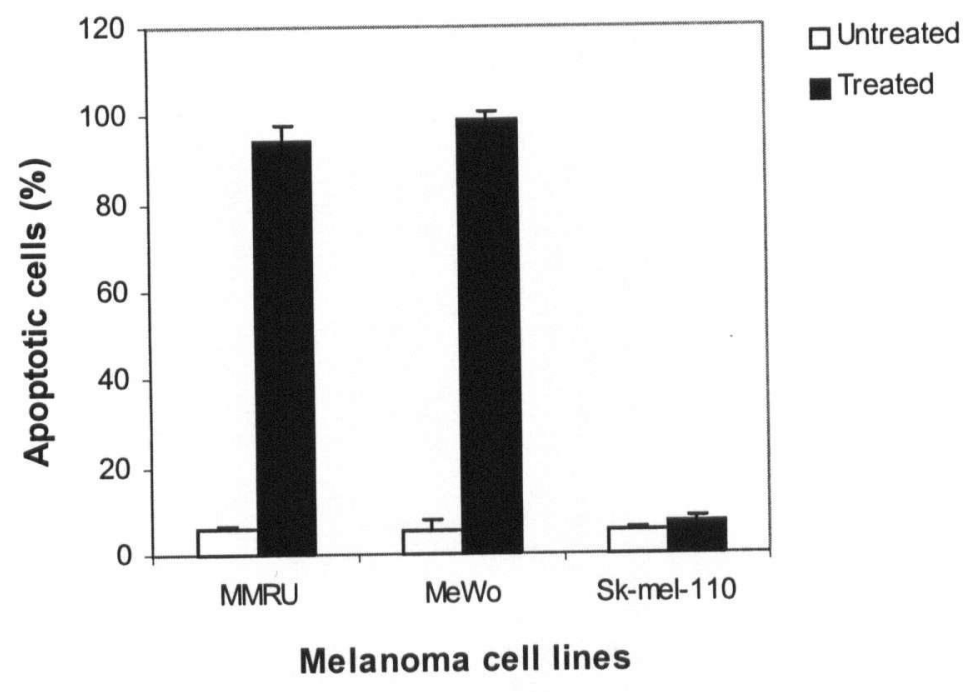


data suggest that CP-31398 induced apoptosis by altering mitochondrial membrane potential.

\subsubsection{Induction of cytochrome $c$ release}

A change in mitochondrial membrane potential is usually coupled with cytochrome $c$ release from mitochondria into cytosol (Cryns and Yuan, 1998). Subcellular fractionation and Western blotting were performed to determine if indeed cytochrome $c$ was released from mitochondria to cytosol in melanoma cells after treatment with $15 \mu \mathrm{g} \mathrm{mL}^{-1}$ of CP31398. Our results indicated that the cytochrome $c$ level only decreased in the mitochondria and increased in the cytosol in CP-31398 sensitive MMRU and MeWo cells, while little cytochrome $c$ release occurred in Sk-mel-1 10 cells (Fig. 3.10). 
Figure 3.10 Effect of CP-31398 on cytochrome $c$ release. Subcellular fractionation and Western blot analysis were performed on proteins extracted from MMRU, MeWo and Skmel-110 cells treated with 0 or $15 \mu \mathrm{g} \mathrm{mL}^{-1}$ of CP-31398 for $16 \mathrm{~h}$. Antibody against cytochrome $c$ was used. $\beta$-actin was used as a loading control for the cytosolic fraction.

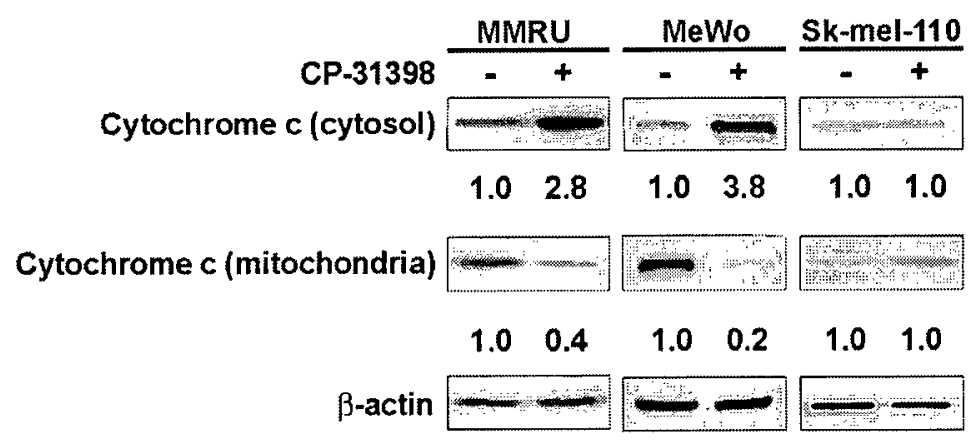




\subsubsection{CP-31398 does not induce Apaf-1 expression}

Once released from mitochondria, cytochrome $c$ often binds to Apaf-1 and activates procaspases. Previous studies have shown that $\mathrm{p} 53$ can directly regulate Apaf- 1 mRNA and protein levels during apoptosis (Robles et al., 2001). After exposure to DNA-damaging agents, it has been shown that wild-type p53 can induce Apaf-1 mRNA and protein expression (Soengas et al., 2001). Others have shown that metastatic melanomas often lose Apaf-1 (Roses et al., 1991a) and Apaf-1 negative melanomas were invariably chemoresistant. Our Western blot analysis showed that Apaf-1 protein was expressed but the level did not change extensively in all three melanoma cell lines after CP-31398 treatment (Fig. 3.11), suggesting that p53 did not regulate Apaf-1 protein level in these cells during CP-31398-mediated apoptosis.

\subsubsection{Activation of Caspases- 9 and $\mathbf{- 3}$}

Released cytochrome $c$ often facilitates the interaction between Apaf-1 and caspase-9, resulting in the activation of caspase- 9 and downstream effector caspases such as caspase-3 and -7 (Kannan et al., 2001; Moroni et al., 2001). To determine if the mitochondrial or caspase-9 pathway is activated in CP-31398-induced apoptosis, we analyzed the cleavage of caspase- 9 by Western blotting. Fig. 3.11 shows that the pro-caspase- 9 level is dramatically reduced after CP-31398 treatment in both MMRU and MeWo cells, while little change was observed in Sk-mel-110 cells. Since activated caspase-9 can cleave caspases-3 and -7, we further examined the pro-caspase-3 level after CP-31398 treatment. We found that CP-31398 reduced pro-caspase-3 level substantially in both MMRU and MeWo cells, while negligible changes in Sk-mel-110 cells were observed (Fig. 3.11). 
Figure 3.11 Effect of CP-31398 on the expression of Apaf-1, pro-caspases-9 and -3 . CP-31398 reduced pro-caspases-9 and -3 protein levels but not Apaf-1. MMRU, MeWo and Sk-mel-110 cells were treated with 0 or $15 \mu \mathrm{g} \mathrm{mL}^{-1}$ of CP-31398 for 0,8 , or $16 \mathrm{~h}$. Proteins were extracted and subjected to Western blot analysis using anti-caspase-9, anticaspase-3, and anti-Apaf-1 antibodies. $\beta$-actin was used as a loading control.

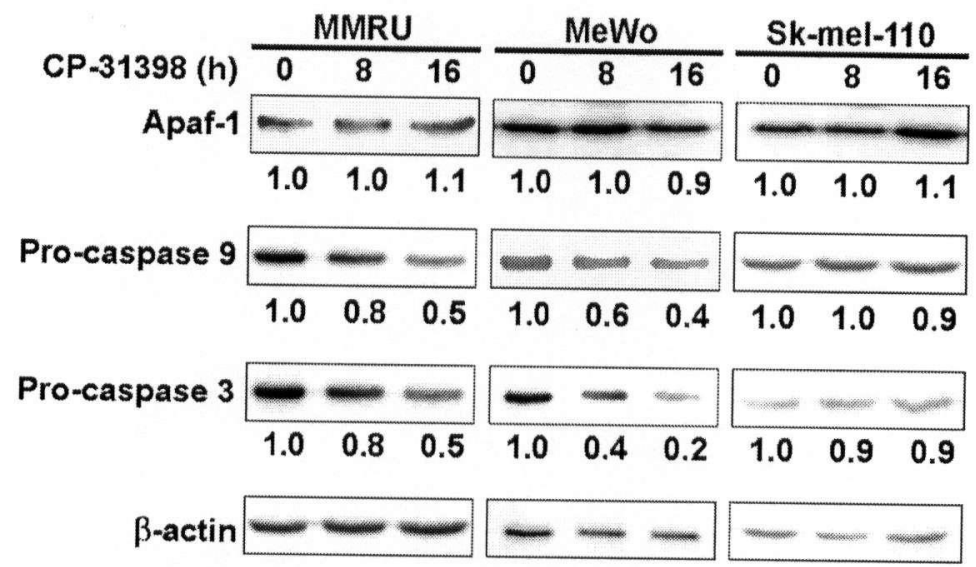




\subsubsection{CP-31398-induced apoptosis does not involve Fas receptor or Fas-ligand}

Since p53 is involved in both the mitochondrial- and death receptor-mediated apoptosis pathways, we investigated if Fas death receptor pathway was involved in CP-31398mediated apoptosis in human melanoma cells. We showed that neither Fas nor Fas-ligand (Fas-L) protein level was changed considerably (Fig. 3.12), indicating that Fas death receptor pathway probably did not participate in CP-31398 mediated apoptosis. 
Figure 3.12 CP-31398 did not alter the expression of Fas and Fas-ligand proteins. MMRU, MeWo and Sk-mel-110 cells were treated with 0 or $15 \mu \mathrm{g} \mathrm{mL} \mathrm{m}^{-1}$ of CP-31398 for 0,8 , or $16 \mathrm{~h}$. Proteins were extracted and subjected to Western blot analysis using anti-Fas or anti-Fas-ligand (Fas-L) antibody was performed on proteins extracted in. $\beta$-actin was used as a loading control.

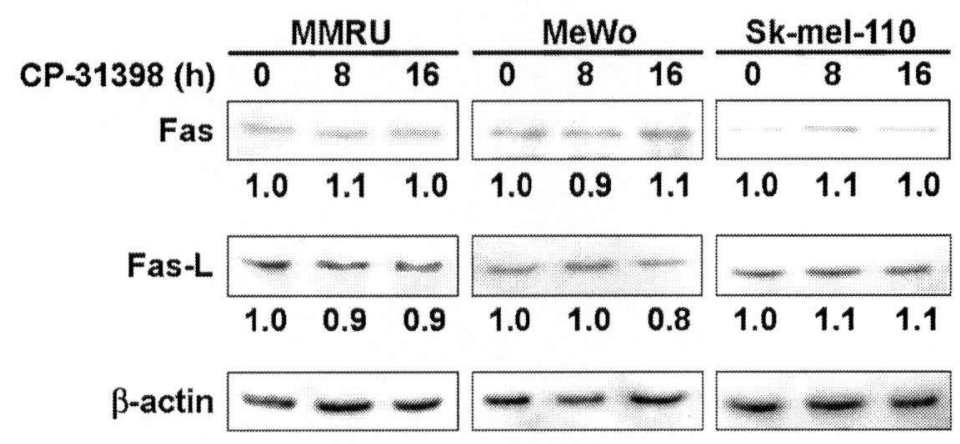




\subsection{Discussion}

In approximately $50 \%$ of all human tumours, the $p 53$ tumour suppressor gene is inactivated by point mutations. Such a high mutation frequency indicates a strong selection for loss of normal p53 function during tumourigenesis (Soussi, 2000). One way to introduce wild-type p53 gene into tumour cells is through viral mediated vectors such as adenovirus and retrovirus. Besides high toxicity, the use of viral delivery systems may involve an immuno-response to viral antigens (Walther and Stein, 2000). Another approach is to stabilize the $\mathrm{p} 53$ protein in an active conformation which may help prolong its anti-tumour effects. A library of synthetic compounds was screened recently in an effort to identify small molecules that has the ability to stabilize the native conformation of p53 and to rescue mutant p53 (Foster et al., 1999). Conformation-specific antibodies PAb1620 and PAb240, which recognize the folded and unfolded conformations of p53 respectively, were used to evaluate the capability of compounds to stabilize the active conformation of the wild-type p53 core domain upon thermal denaturation.

The most promising molecule, CP-31398, enhanced the stability of Ala-173 and His-273 mutant p53 core domains in vitro. It restored native conformation and activated transcriptional activity to Ala-173 mutant p53 in living cells, causing an induction of a p53 target gene p21 ${ }^{\text {Wafl }}$ (Foster et al., 1999). Moreover, CP-31398 inhibited the growth of human colon carcinoma and melanoma cells carrying mutated p53 at position 241 or 249 , respectively, in nude mice. Additionally, no toxicity was observed at the therapeutic doses in vivo (Foster et al., 1999; Bykov et al., 2003).

At present, the exact mechanism of CP-31398 inhibition of tumour growth remains controversial. The capability of this compound to interact directly with already 
synthesized $\mathrm{p} 53^{3}$ or mediate $\mathrm{p} 53$ folding during biosynthesis is still uncertain. The first attempt to detect physical interactions between p53 and CP-31398 was unsuccessful. Nuclear magnetic resonance (NMR) failed to show CP-31398 binds to the DNA binding core domain of either recombinant wild-type or mutant p53. Rather, gel shift assays and NMR indicated that the compound binds DNA. Some experimental evidence suggests that CP-31398 can affect the folding of newly synthesized p53 only, which could explain the negative NMR results (Rippin et al., 2002).

CP-31398-induced apoptosis may contribute to its inhibitory effect on tumour growth. Our group used colon rectal cancer cells HCT116 that carries wild-type p53 and its isogenic p53-null cell line in which wild-type p53 has been knocked out. We found that CP-31398 only induced apoptosis in HCT116 cells that carries wild-type p53, but not in the p53-null line (Luu et al., 2002). In addition, we found that CP-31398 enhances UVB induced apoptosis in MMRU melanoma cells by activating the p53-mitochondrial pathway (Luu and Li, 2002). Tumour cell lines that contain mutant p53 seem to respond differently to CP-31398-induced apoptosis. Takimoto and colleagues (2002) reported that after CP31398 treatment mutant-p53 SW480 colon cancer cells underwent apoptosis. However, CP-31398 induced cell cycle arrest exclusively in mutant-p53 H460 lung cancer cells and DLD1 colon cancer cells.

Our results presented a differential survival rate in three melanoma cell lines after CP-31398 treatment. We first demonstrated that the survival of melanoma cell lines after $20 \mathrm{~h}$ of CP-31398 treatment is dose-dependent (Fig.3.1). When cells were treated with more than $30 \mu \mathrm{g} \mathrm{mL}^{-1}$ of $\mathrm{CP}-31398$, all three cell lines underwent apoptosis. This might due to the reactive oxygen species induced by the toxicity of CP-31398 and induced p53- 
independent apoptosis as others have previous reported (Wischhusen et al., 2003). The $\mathrm{EC}_{50}$ (effective concentration 50\%) of CP-31398 for MMRU and MeWo was determined to be $15 \mu \mathrm{g} \mathrm{mL}^{-1}$ and this concentration was used for subsequent experiments. At a moderate concentration, CP-31398 is only effective in wild-type p53 MMRU and single p53 mutant MeWo cells. These two cell lines showed a significant decrease in cell survival, while the Sk-mel-110 cell line which contains multiple p53 mutations had very little change in cell survival after CP-31398 treatment (Fig. 3.2). Programmed cell death was further confirmed in MMRU and MeWo, but not in Sk-mel-110 cells, by DNA laddering assay as apoptotic cells are characterized by DNA condensation and fragmentation (Fig 3.3). Morphological changes can also be observed as membrane blebbing, nuclear condensation, DNA fragmentation, and prominent apoptotic bodies (Fig. $3.4)$.

These results triggered our interest in exploring the reasons behind the differential response to this new synthetic compound. Previous works have indicated that CP-31398 could stabilize both wild-type p53 and mutant p53 unanimously (Foster et al., 1999; Hupp et al., 2000; Rippin et al., 2002). However, the ability of this compound to stabilize mutant p53 may depend on the location of $\mathrm{p} 53$ point mutation, which might account for the observed differential response in two mutant $p 53$ melanoma cell lines that we used. We first confirmed the p53-stabilizing effect of CP-31398 by observing a gradual accumulation of overall p53 protein in all melanoma cell lines over a period of $16 \mathrm{~h}$ by Western blot analysis (Fig. 3.6). Immunofluorescent staining showed only MMRU and MeWo cells had an upregulation of $\mathrm{p} 53$ protein in active conformation after $15 \mu \mathrm{g} \mathrm{mL}^{-1}$ of CP-31398 treatment (Fig. 3.7). Although Sk-mel-110 cells also showed an increase in the 
overall p53 protein level, p53 failed to retain an active conformation in this cell line as determined by immunofluorescent staining. In fact, it has been indicated that Sk-mel-110 carries a non-functional p53 gene product (Takimoto et al., 2002); thus, our observation that the Sk-mel-110 cell line is resistant to CP-31398-induced apoptosis is consistent with the fact that it lacks a functional p53. It appears that both the location and the number of p53 mutations may determine the capability of CP-31398 to restore p53 active conformation and thus induce apoptosis. However, additional studies are required to further prove this notion.

As a transcriptional factor, p53 is capable to activate or repress its downstream genes in order to exert its biological and biochemical functions. One of the welldocumented $\mathrm{p} 53$ downstream effectors is $\mathrm{p} 21^{\text {Wafl }}$, which is involved in cell cycle arrest $(\mathrm{Yu}$ et al., 1998). Our result showed an enhanced $\mathrm{p} 21^{\text {Wafl }}$ transcriptional activity in all three cell lines regardless of their sensitivity to CP-31398 (Fig 3.8), indicating that CP-31398 has the ability to enhance $\mathrm{p} 21^{\text {Wafl }}$ transcription activity independent of p53 mutation status or sensitivity to CP-31398. Additionally, $\mathrm{p} 21^{\text {Wafl }}$ transcription might be enhanced through a p53-independent pathway (DiGiuseppe et al., 1995). The seemingly different results reported by Tanner and Barneris (2004) on the effect of CP-31398 for $\mathrm{p} 21^{\text {Wafl }}$ promoter activity may simply due to luciferase assay they used, as in the control H1299 cells transfected with wild-type p53 the exposure of CP-31398 caused a reduction rather than an induction in the expression of the reporter gene. However, Foster and colleagues (1999) as well as this study using Western blotting and RT-PCR found that $\mathrm{p} 21^{\text {Wafl }}$ expression is upregulated by CP-31398 regardless of the apoptotic response in H1299 lung carcinoma cells and melanoma cells, respectively. 
In contrast, the apoptotic downstream transcriptional targets of p53 showed a correlation between CP-31398 and p53 mutation status. The delicate balance between proapoptotic targets (such as Bax and PUMA) and anti-apoptotic (such as Bcl-2 and Bcl-xL) factors seem to be the determinant if a cell undergoes apoptosis or not. One of these targets we looked at was the mitochondrial protein Bax. Studies have indicated that p53 induced apoptosis requires Bax to activate caspases-9 and -3 through mitochondrial cytochrome $c$ release in human osteosarcoma Saos-2 cells (Narita et al., 1998; Shimizu et al., 1999). A number of studies have shown a relationship between p53 and yet another mitochondrial protein, PUMA, during apoptosis. PUMA promotes the translocation and multimerization of Bcl-2 family proteins, including Bax, in the mitochondria after binding to them. This is followed by a change in mitochondrial membrane potential, the release of cytochrome $c$ from the mitochondria into the cytosol, and a cascade of caspase activation, resulting in programmed cell death (Nakano and Vousden, 2001; Yu et al., 2003).

We noted an enhanced expression in both Bax and PUMA only in CP-31398 sensitive MMRU and MeWo, but not in CP-31398 resistant Sk-mel-110 cells (Fig. 3.8). This observation is consistent with the ability of CP-31398 to restore and stabilize p53 active conformation, activate transcription of other downstream targets, and induce apoptosis (Luu et al., 2002). Sk-mel-110 cells on the other hand have consistently a relatively high background level of Bax and PUMA transcription indicating that other factors, which might due to a high level of anti-apoptotic proteins, contribute to its resistance to CP-31398 induced apoptosis.

We further demonstrated a series of apoptotic events from the alteration of mitochondrial membrane potential (Fig. 3.9), the release of cytochrome $c$ from 
mitochondria (Fig. 3.10), to the reduction in the levels of pro-caspases-9 and -3 (Fig. 3.11) in CP-31398 sensitive MMRU and MeWo cells. None of these changes were observed in CP-31398 resistant Sk-mel-110 cells. These findings are consistent with the previous studies showing that active $\mathrm{p} 53$ has the capacity to activate the Bax/mitochondrial/caspase9 apoptosis pathway (Pearson et al., 2000).

It is of interest to point out that the level of a p53 downstream scaffolding protein, Apaf-1, did not change in all three melanoma cell lines after CP-31398 treatment. This indicates that Apaf-1 was not involved in CP-31398 mediated apoptosis (Fig 3.11). Likewise, others have recently reported that activation of caspase-9 is independent of Apaf-1 expression in melanoma cells (Zanon et al., 2004). In particular, Apaf-1 protein expression in Sk-mel-110 cells ruled out the possibility that resistance of this cell line to CP-31398 treatment was due to the loss of Apaf-1. Moreover, we showed that both Fas and Fas-ligand protein level did not change considerably in all three melanoma cell lines after CP-31398 regardless of their apoptotic responses (Fig. 3.12). This further confirms that the mitochondrial pathway instead of the Fas death receptor pathway is involved in CP-31398 induced apoptosis.

In conclusion, we demonstrated that after CP-31398 treatment, an increase in the stability of $\mathrm{p} 53$ protein in active conformation that correlates to apoptotic response. Overall, CP-31398 sensitive cell lines showed an increased transcription of Bax and PUMA, an altered mitochondrial membrane potential, a release of cytochrome $c$ from the mitochondria into the cytosol, followed by the cleavage of pro-caspases- 9 and -3 . However, CP-31398 was not able to revert all mutant p53 proteins to wild-type conformation and induce apoptosis in all mutant p53 cell lines. Nonetheless, based on our 
results, the ability for CP-31398 to induce apoptosis through the intrinsic mitochondrial pathway may well depend on the mutational status of p53. Mutant p53 reactivation by small molecules has an evident potential for the discovery of efficient and specific anticancer drugs. More studies are necessary to investigate $p 53$ mutation-dependent response to CP-31398 and explore the potential utilization of this compound as an anticancer agent. 


\section{CHAPTER 4. GENERAL CONCLUSIONS}

\subsection{Summary}

p53 is a widely-studied tumour suppressor that has the ability to trigger cell-cycle arrest and apoptosis in response to diverse stress stimuli. Under cellular stress, such as hypoxia, DNA damage, ionizing radiation, exposure to anticancer drugs, and oncogene activation, the p53 protein is rapidly accumulated in a cell. This increase in p53 protein level can further transactivate its downstream target genes through specific DNA binding. Depending on the extent of DNA damage, p53 can either bring about cell cycle arrest in an effort to repair the damage, or induce apoptosis when the damage is too severe. Apoptosis, or programmed cell death, is a tightly regulated self-protective mechanism in order to eliminate unnecessary or severely damaged cells.

More than half of all human tumours contain p53 mutations and majority of the mutations are located in the DNA binding domain. The prevalent disruption of the specific DNA binding function of $\mathrm{p} 53$ by gene mutation suggests that this function is critical for p53-mediated tumour suppression. Many conventional chemotherapeutic agents exploit this p53-dependent apoptotic pathway through DNA damaging events to destroy cancerous cells. Conventional therapeutic agents amplify the stress signals, impelling damaged cells to self-destruct. Unfortunately, treatment fails when the cancer inactivates tumoursuppressor pathways. In most malignancies, mutation in p53 leads to a shut down of the p53 tumour suppressor signaling pathway. Various strategies have been explored to restore mutant $\mathrm{p} 53$ to wild-type function. A class of small pharmacological peptide has been identified in a random screening. This class of small-molecule compounds can 
promote the stable active conformation of wild-type p53, increase the activity of p53 and induce apoptosis in tumour cells. Among all, CP-31398 showed the strongest ability to stabilize the wild-type p53 protein conformation against thermal denaturation and has a remarkable capacity to restore mutant p53 to behave like wild-type p53 and induce apoptosis.

As metastatic melanoma responses poorly to traditional treatment methods, we sought to explore the possibility of using this new small molecule drug as a treatment for melanoma cells with various p53 mutation statuses. Noticing a differential response of melanoma cell lines to CP-31398 after initial screening, we hypothesized that the ability of CP-31398 to revert mutant p53 to wild-type p53 conformation may not be universal. Using three human melanoma cell lines, MMRU, which contains wild-type p53, and MeWo and Sk-mel-110, which carries mutant p53, we demonstrated that CP-31398 triggers apoptosis in some melanoma cell lines. Upon a moderate dose of CP-31398 treatment at $\mathrm{EC}_{50}\left(15 \mu \mathrm{g} \mathrm{mL} \mathrm{m}^{-1}\right)$, only MMRU (wild-type p53) and MeWo (single point mutation in the $p 53$ gene) cells exhibited apoptosis. With multiple p53 mutations, Sk-mel110 cells did not respond at this moderate concentration. In spite of the fact that all three melanoma cell lines showed an increase in the overall p53 protein levels, only CP-31398 sensitive cell lines, MMRU and MeWo, exhibited a significantly detectable increase in active wild-type p53 conformation. Additionally, CP-31398 induced the expression of p53 downstream transcriptional targets including Bax and PUMA, altered the mitochondrial membrane potential, and enhanced the release of cytochrome $c$ and activation of caspases9 and -3 in CP-31398 sensitive cell lines, but not in multiple p53-mutation Sk-mel-110 cells. 


\subsection{Future Directions}

With a steady increase in the incidence of melanoma, an effective treatment method is imminent. Although surgical removal of metastatic tumours may provide some benefit by easing pain, increasing the general quality of life, and lengthening survival, advanced melanoma that has spread to distant sites often cannot be cured.

In this thesis, we demonstrated that after CP-31398 treatment, the stability of p53 protein in active conformation increases which also correlates to apoptotic response. We showed that mutant p53 melanoma cell lines respond differently to CP-31398 induced apoptosis. Our results strongly suggest that CP-31398 may induce apoptosis in a p53mutation specific manner. To test this hypothesis, isogenic cell line expressing either wildtype $p 53$ or a variety of mutant $p 53$ should be used. It would be beneficial, through site directed mutagenesis, to identify the key location in $p 53$ that is responsible for CP-31398 induced apoptosis.

Since p53 mutation is rare in melanoma (Hussein et al., 2003) and we clearly showed that CP-31398 successfully induced apoptosis in a melanoma cell line expressing wild-type p53, MMRU, efforts should be made for this compound in clinical trials for treating melanoma patients. Previous study has established the low toxicity of CP-31398 in in vivo animal studies, which further favours the clinical trial (Foster et al., 1999; Bykov et al., 2003).

Besides skin cancer, CP-31398 may also be used for treating other type of cancers. For instance, our group and others have shown that this compound can induce apoptosis in HCT116 colon cancer cells (Luu et al., 2002) and SW480 colon cancer cells (Takimoto et al., 2002). In this thesis, we also showed that CP-31398 can induce apoptosis in Mewo 
cell line, which contains a single point mutation. Other studies noted a similar observation in other cell lines that contain single point mutations (Foster et al., 1999; Takimoto et al., 2002). As over $50 \%$ of $p 53$ inactivation is due to single point mutation (Soussi, 2000), CP31398 may hold potential to convert most mutant $p 53$ with single point mutation to wildtype conformation, and induce apoptosis. Mutant $p 53$ reactivation by small molecules has an evident potential for the discovery of effective and specific anti-cancer drugs. More studies are necessary to investigate $p 53$ mutation-dependent response to CP-31398 and explore the potential utilization of this compound as a potential anticancer therapeutic agent. 


\section{REFERENCES}

Albino, A.P., M.J. Vidal, N.S. McNutt, C.R. Shea, V.G. Prieto, D.M. Nanus, J.M. Palmer, and N.K. Hayward. 1994. Mutation and expression of the p53 gene in human malignant melanoma. Melanoma Res. 4:35-45.

Alcalay, J., S.E. Freeman, L.H. Goldberg, and J.E. Wolf. 1990. Excision repair of pyrimidine dimers induced by simulated solar radiation in the skin of patients with basal cell carcinoma. J Invest Dermatol. 95:506-509.

Armstrong, B.K., and A. Kricker. 1993. How much melanoma is caused by sun exposure? Melanoma Res. 3:395-401.

Ashkenazi, A., and V.M. Dixit. 1998. Death receptors: signaling and modulation. Science. 281:1305-1308.

Asker, C., K.G. Wiman, and G. Selivanova. 1999. p53-induced apoptosis as a safeguard against cancer. Biochem Biophys Res Commun. 265:1-6.

Atillasoy, E.S., J.T. Seykora, P.W. Soballe, R. Elenitsas, M. Nesbit, D.E. Elder, K.T. Montone, E. Sauter, and M. Herlyn. 1998. UVB induces atypical melanocytic lesions and melanoma in human skin. Am J Pathol. 152:1179-1186.

Baker, S.J., E.R. Fearon, J.M. Nigro, S.R. Hamilton, A.C. Preisinger, J.M. Jessup, P. vanTuinen, D.H. Ledbetter, D.F. Barker, Y. Nakamura, and et al. 1989. Chromosome 17 deletions and p53 gene mutations in colorectal carcinomas. Science. 244:217-221.

Baker, S.J., S. Markowitz, E.R. Fearon, J.K. Willson, and B. Vogelstein. 1990. Suppression of human colorectal carcinoma cell growth by wild-type p53. Science. 249:912-915. 
Barak, Y., T. Juven, R. Haffner, and M. Oren. 1993. mdm2 expression is induced by wild type p53 activity. Embo $J .12: 461-468$.

Bargonetti, J., J.J. Manfredi, X. Chen, D.R. Marshak, and C. Prives. 1993. A proteolytic fragment from the central region of p53 has marked sequence-specific DNAbinding activity when generated from wild-type but not from oncogenic mutant $\mathrm{p} 53$ protein. Genes Dev. 7:2565-2574.

Barry, M.A., C.A. Behnke, and A. Eastman. 1990. Activation of programmed cell death (apoptosis) by cisplatin, other anticancer drugs, toxins and hyperthermia. Biochem Pharmacol. 40:2353-2362.

Bates, S., K.M. Ryan, A.C. Phillips, and K.H. Vousden. 1998. Cell cycle arrest and DNA endoreduplication following p21Waf1/Cip1 expression. Oncogene. 17:1691-1703.

Bennett, M., K. Macdonald, S.W. Chan, J.P. Luzio, R. Simari, and P. Weissberg. 1998. Cell surface trafficking of Fas: a rapid mechanism of p53-mediated apoptosis. Science. 282:290-293.

Beroud, C., and T. Soussi. 1998. p53 gene mutation: software and database. Nucleic Acids Res. 26:200-204.

Boni, R., C. Schuster, B. Nehrhoff, and G. Burg. 2002. Epidemiology of skin cancer. Neuro Endocrinol Lett. 23 Suppl 2:48-51.

Brachmann, R.K., M. Vidal, and J.D. Boeke. 1996. Dominant-negative p53 mutations selected in yeast hit cancer hot spots. Proc Natl Acad Sci U S A. 93:4091-4095.

Bullock, A.N., and A.R. Fersht. 2001. Rescuing the function of mutant p53. Nat Rev Cancer. 1:68-76. 
Burnette, W.N. 1981. "Western blotting": electrophoretic transfer of proteins from sodium dodecyl sulfate--polyacrylamide gels to unmodified nitrocellulose and radiographic detection with antibody and radioiodinated protein A. Anal Biochem. 112:195-203.

Butt, A.J., S.M. Firth, M.A. King, and R.C. Baxter. 2000. Insulin-like growth factorbinding protein- 3 modulates expression of $\mathrm{Bax}$ and $\mathrm{Bcl}-2$ and potentiates p53independent radiation-induced apoptosis in human breast cancer cells. J Biol Chem. 275:39174-39181.

Byers, H.R., T. Etoh, J.R. Doherty, A.J. Sober, and M.C. Mihm, Jr. 1991. Cell migration and actin organization in cultured human primary, recurrent cutaneous and metastatic melanoma. Time-lapse and image analysis. Am J Pathol. 139:423-435.

Bykov, V.J., N. Issaeva, A. Shilov, M. Hultcrantz, E. Pugacheva, P. Chumakov, J. Bergman, K.G. Wiman, and G. Selivanova. 2002. Restoration of the tumor suppressor function to mutant p53 by a low-molecular-weight compound. Nat Med. 8:282-288.

Bykov, V.J., G. Selivanova, and K.G. Wiman. 2003. Small molecules that reactivate mutant p53. Eur J Cancer. 39:1828-1834.

Chellappan, S.P., S. Hiebert, M. Mudryj, J.M. Horowitz, and J.R. Nevins. 1991. The E2F transcription factor is a cellular target for the RB protein. Cell. 65:1053-1061.

Chen, J., J. Lin, and A.J. Levine. 1995. Regulation of transcription functions of the p53 tumor suppressor by the mdm-2 oncogene. Mol Med. 1:142-152.

Chernov, M.V., and G.R. Stark. 1997. The p53 activation and apoptosis induced by DNA damage are reversibly inhibited by salicylate. Oncogene. 14:2503-2510. 
Chinnaiyan, A.M., K. O'Rourke, M. Tewari, and V.M. Dixit. 1995. FADD, a novel death domain-containing protein, interacts with the death domain of Fas and initiates apoptosis. Cell. 81:505-512.

Cho, Y., S. Gorina, P.D. Jeffrey, and N.P. Pavletich. 1994. Crystal structure of a p53 tumor suppressor-DNA complex: understanding tumorigenic mutations. Science. 265:346-355.

Clarke, A.R., C.A. Purdie, D.J. Harrison, R.G. Morris, C.C. Bird, M.L. Hooper, and A.H. Wyllie. 1993. Thymocyte apoptosis induced by p53-dependent and independent pathways. Nature. 362:849-852.

Cryns, V., and J. Yuan. 1998. Proteases to die for. Genes Dev. 12:1551-1570.

de Gruijl, F.R., H.J. van Kranen, and L.H. Mullenders. 2001. UV-induced DNA damage, repair, mutations and oncogenic pathways in skin cancer. $J$ Photochem Photobiol B. 63:19-27.

de Vries, A., E.R. Flores, B. Miranda, H.M. Hsieh, C.T. van Oostrom, J. Sage, and T. Jacks. 2002. Targeted point mutations of p53 lead to dominant-negative inhibition of wild-type p53 function. Proc Natl Acad Sci U S A. 99:2948-2953.

DeGregori, J., T. Kowalik, and J.R. Nevins. 1995. Cellular targets for activation by the E2F1 transcription factor include DNA synthesis- and G1/S-regulatory genes. Mol Cell Biol. 15:4215-4224.

Delavaine, L., and N.B. La Thangue. 1999. Control of E2F activity by $\mathrm{p} 21$ Wafl/Cip1. Oncogene. 18:5381-5392. 
DiGiuseppe, J.A., M.S. Redston, C.J. Yeo, S.E. Kern, and R.H. Hruban. 1995. p53independent expression of the cyclin-dependent kinase inhibitor p21 in pancreatic carcinoma. Am J Pathol. 147:884-888.

Dittmer, D., S. Pati, G. Zambetti, S. Chu, A.K. Teresky, M. Moore, C. Finlay, and A.J. Levine. 1993. Gain of function mutations in p53. Nat Genet. 4:42-46.

Dobrowolski, R., R. Hein, R. Buettner, and A.K. Bosserhoff. 2002. Loss of p14ARF expression in melanoma. Arch Dermatol Res. 293:545-551.

Donehower, L.A., M. Harvey, B.L. Slagle, M.J. McArthur, C.A. Montgomery, Jr., J.S. Butel, and A. Bradley. 1992. Mice deficient for p53 are developmentally normal but susceptible to spontaneous tumours. Nature. 356:215-221.

Dulic, V., G.H. Stein, D.F. Far, and S.I. Reed. 1998. Nuclear accumulation of p21Cip1 at the onset of mitosis: a role at the G2/M-phase transition. Mol Cell Biol. 18:546557.

Dunlap, S., X. Yu, L. Cheng, C.I. Civin, and R.M. Alani. 2004. High-efficiency stable gene transduction in primary human melanocytes using a lentiviral expression system. J Invest Dermatol. 122:549-551.

Earnshaw, W.C., L.M. Martins, and S.H. Kaufmann. 1999. Mammalian caspases: structure, activation, substrates, and functions during apoptosis. Annu Rev Biochem. $68: 383-424$

el-Deiry, W.S. 1998. Regulation of p53 downstream genes. Semin Cancer Biol. 8:345-357. el-Deiry, W.S., S.E. Kern, J.A. Pietenpol, K.W. Kinzler, and B. Vogelstein. 1992. Definition of a consensus binding site for p53. Nat Genet. 1:45-49. 
el-Deiry, W.S., T. Tokino, V.E. Velculescu, D.B. Levy, R. Parsons, J.M. Trent, D. Lin, W.E. Mercer, K.W. Kinzler, and B. Vogelstein. 1993. WAF1, a potential mediator of p53 tumor suppression. Cell. 75:817-825.

Eliyahu, D., D. Michalovitz, S. Eliyahu, O. Pinhasi-Kimhi, and M. Oren. 1989. Wild-type p53 can inhibit oncogene-mediated focus formation. Proc Natl Acad Sci U S A. 86:8763-8767.

Eliyahu, D., A. Raz, P. Gruss, D. Givol, and M. Oren. 1984. Participation of p53 cellular tumour antigen in transformation of normal embryonic cells. Nature. 312:646-649.

Embree-Ku, M., D. Venturini, and K. Boekelheide. 2002. Fas is involved in the p53dependent apoptotic response to ionizing radiation in mouse testis. Biol Reprod. $66: 1456-1461$.

Fan, S., W.S. el-Deiry, I. Bae, J. Freeman, D. Jondle, K. Bhatia, A.J. Fornace, Jr., I. Magrath, K.W. Kohn, and P.M. O'Connor. 1994. p53 gene mutations are associated with decreased sensitivity of human lymphoma cells to DNA damaging agents. Cancer Res. 54:5824-5830.

Farmer, G., J. Bargonetti, H. Zhu, P. Friedman, R. Prywes, and C. Prives. 1992. Wild-type p53 activates transcription in vitro. Nature. 358:83-86.

Fields, S., and S.K. Jang. 1990. Presence of a potent transcription activating sequence in the p53 protein. Science. 249:1046-1049.

Finlay, C.A., P.W. Hinds, and A.J. Levine. 1989. The p53 proto-oncogene can act as a suppressor of transformation. Cell. 57:1083-1093.

FitzGerald, M.G., D.P. Harkin, S. Silva-Arrieta, D.J. MacDonald, L.C. Lucchina, H. Unsal, E. O'Neill, J. Koh, D.M. Finkelstein, K.J. Isselbacher, A.J. Sober, and D.A. 
Haber. 1996. Prevalence of germ-line mutations in p16, p19ARF, and CDK4 in familial melanoma: analysis of a clinic-based population. Proc Natl Acad Sci U S A. 93:8541-8545.

Ford, J.M., and P.C. Hanawalt. 1995. Li-Fraumeni syndrome fibroblasts homozygous for p53 mutations are deficient in global DNA repair but exhibit normal transcriptioncoupled repair and enhanced UV resistance. Proc Natl Acad Sci U S A. 92:88768880.

Foster, B.A., H.A. Coffey, M.J. Morin, and F. Rastinejad. 1999. Pharmacological rescue of mutant p53 conformation and function. Science. 286:2507-2510.

Fotedar, R., P. Fitzgerald, T. Rousselle, D. Cannella, M. Doree, H. Messier, and A. Fotedar. 1996. p21 contains independent binding sites for cyclin and cdk2: both sites are required to inhibit cdk2 kinase activity. Oncogene. 12:2155-2164.

Freedman, D.A., and A.J. Levine. 1998. Nuclear export is required for degradation of endogenous p53 by MDM2 and human papillomavirus E6. Mol Cell Biol. 18:72887293.

Fuchs, E.J., K.A. McKenna, and A. Bedi. 1997. p53-dependent DNA damage-induced apoptosis requires Fas/APO-1-independent activation of CPP32beta. Cancer Res. $57: 2550-2554$.

Fuchs, S.Y., V. Adler, T. Buschmann, X. Wu, and Z. Ronai. 1998. Mdm2 association with p53 targets its ubiquitination. Oncogene. 17:2543-2547.

Fukasawa, K., F. Wiener, G.F. Vande Woude, and S. Mai. 1997. Genomic instability and apoptosis are frequent in p53 deficient young mice. Oncogene. 15:1295-1302. 
Fukazawa, T., T. Fujiwara, Y. Morimoto, J. Shao, M. Nishizaki, Y. Kadowaki, A. Hizuta, L.B. Owen-Schaub, J.A. Roth, and N. Tanaka. 1999. Differential involvement of the CD95 (Fas/APO-1) receptor/ligand system on apoptosis induced by the wildtype p53 gene transfer in human cancer cells. Oncogene. 18:2189-2199.

Gamble, J., and J. Milner. 1988. Evidence that immunological variants of p53 represent alternative protein conformations. Virology. 162:452-458.

Garbe, C. 1993. Chemotherapy and chemoimmunotherapy in disseminated malignant melanoma. Melanoma Res. 3:291-299.

Giaccia, A.J., and M.B. Kastan. 1998. The complexity of p53 modulation: emerging patterns from divergent signals. Genes Dev. 12:2973-2983.

Gottesman, M.M., and I. Pastan. 1993. Biochemistry of multidrug resistance mediated by the multidrug transporter. Annu Rev Biochem. 62:385-427.

Green, D.R., and J.C. Reed. 1998. Mitochondria and apoptosis. Science. 281:1309-1312.

Hachiya, M., A. Chumakov, C.W. Miller, M. Akashi, J. Said, and H.P. Koeffler. 1994. Mutant p53 proteins behave in a dominant, negative fashion in vivo. Anticancer Res. 14:1853-1859.

Hara, I., H. Miyake, S. Hara, S. Arakawa, and S. Kamidono. 2000. Differential involvement of the Fas receptor/ligand system in p53-dependent apoptosis in human prostate cancer cells. Prostate. 45:341-349.

Harper, J.W., G.R. Adami, N. Wei, K. Keyomarsi, and S.J. Elledge. 1993. The p21 Cdkinteracting protein Cip1 is a potent inhibitor of G1 cyclin-dependent kinases. Cell. $75: 805-816$ 
Haupt, Y., R. Maya, A. Kazaz, and M. Oren. 1997. Mdm2 promotes the rapid degradation of p53. Nature. 387:296-299.

Hayakawa, K., M. Hasegawa, M. Kawashima, Y. Nakamura, M. Matsuura, H. Toda, N. Mitsuhashi, and H. Niibe. 2000. Comparison of effects of doxorubicin and radiation on p53-dependent apoptosis in vivo. Oncol Rep. 7:267-270.

Healy, E., C.E. Belgaid, M. Takata, A. Vahlquist, I. Rehman, H. Rigby, and J.L. Rees. 1996. Allelotypes of primary cutaneous melanoma and benign melanocytic nevi. Cancer Res. 56:589-593.

Helmbach, H., E. Rossmann, M.A. Kern, and D. Schadendorf. 2001. Drug-resistance in human melanoma. Int J Cancer. 93:617-622.

Hermeking, H., C. Lengauer, K. Polyak, T.C. He, L. Zhang, S. Thiagalingam, K.W. Kinzler, and B. Vogelstein. 1997. 14-3-3 sigma is a p53-regulated inhibitor of G2/M progression. Mol Cell. 1:3-11.

Hirata, H., A. Takahashi, S. Kobayashi, S. Yonehara, H. Sawai, T. Okazaki, K. Yamamoto, and M. Sasada. 1998. Caspases are activated in a branched protease cascade and control distinct downstream processes in Fas-induced apoptosis. $J$ Exp Med. 187:587-600.

Hollstein, M., B. Shomer, M. Greenblatt, T. Soussi, E. Hovig, R. Montesano, and C.C. Harris. 1996. Somatic point mutations in the p53 gene of human tumors and cell lines: updated compilation. Nucleic Acids Res. 24:141-146.

Hollstein, M., D. Sidransky, B. Vogelstein, and C.C. Harris. 1991. p53 mutations in human cancers. Science. 253:49-53. 
Holman, C.D., and B.K. Armstrong. 1984. Cutaneous malignant melanoma and indicators of total accumulated exposure to the sun: an analysis separating histogenetic types. J Natl Cancer Inst. 73:75-82.

Honda, R., H. Tanaka, and H. Yasuda. 1997. Oncoprotein MDM2 is a ubiquitin ligase E3 for tumor suppressor p53. FEBS Lett. 420:25-27.

Honda, R., and H. Yasuda. 1999. Association of p19(ARF) with Mdm2 inhibits ubiquitin ligase activity of Mdm2 for tumor suppressor p53. Embo J. 18:22-27.

Hupp, T.R., D.P. Lane, and K.L. Ball. 2000. Strategies for manipulating the p53 pathway in the treatment of human cancer. Biochem J. $352 \mathrm{Pt}$ 1:1-17.

Hussein, M.R., A.K. Haemel, and G.S. Wood. 2003. p53-related pathways and the molecular pathogenesis of melanoma. Eur J Cancer Prev. 12:93-100.

Inagaki-Ohara, K., S. Yada, N. Takamura, M. Reaves, X. Yu, E. Liu, I. Rooney, S. Nicholas, A. Castro, C.F. Ware, D.R. Green, and T. Lin. 2001. p53-dependent radiation-induced crypt intestinal epithelial cells apoptosis is mediated in part through TNF-TNFR1 system. Oncogene. 20:812-818.

Iwabuchi, K., B. Li, P. Bartel, and S. Fields. 1993. Use of the two-hybrid system to identify the domain of p53 involved in oligomerization. Oncogene. 8:1693-1696.

Jiang, X., and X. Wang. 2000. Cytochrome $\mathrm{c}$ promotes caspase-9 activation by inducing nucleotide binding to Apaf-1. J Biol Chem. 275:31199-31203.

Jurgensmeier, J.M., Z. Xie, Q. Deveraux, L. Ellerby, D. Bredesen, and J.C. Reed. 1998. Bax directly induces release of cytochrome $\mathrm{c}$ from isolated mitochondria. Proc Natl Acad Sci US A. 95:4997-5002. 
Kamijo, T., J.D. Weber, G. Zambetti, F. Zindy, M.F. Roussel, and C.J. Sherr. 1998. Functional and physical interactions of the ARF tumor suppressor with $\mathrm{p} 53$ and Mdm2. Proc Natl Acad Sci U S A. 95:8292-8297.

Kannan, K., N. Amariglio, G. Rechavi, J. Jakob-Hirsch, I. Kela, N. Kaminski, G. Getz, E. Domany, and D. Givol. 2001. DNA microarrays identification of primary and secondary target genes regulated by p53. Oncogene. 20:2225-2234.

Karpinich, N.O., M. Tafani, R.J. Rothman, M.A. Russo, and J.L. Farber. 2002. The course of etoposide-induced apoptosis from damage to DNA and p53 activation to mitochondrial release of cytochrome c. J Biol Chem. 277:16547-16552.

Kastan, M.B., O. Onyekwere, D. Sidransky, B. Vogelstein, and R.W. Craig. 1991. Participation of $\mathrm{p} 53$ protein in the cellular response to DNA damage. Cancer Res. $51: 6304-6311$.

Kastan, M.B., Q. Zhan, W.S. el-Deiry, F. Carrier, T. Jacks, W.V. Walsh, B.S. Plunkett, B. Vogelstein, and A.J. Fornace, Jr. 1992. A mammalian cell cycle checkpoint pathway utilizing p53 and GADD45 is defective in ataxia-telangiectasia. Cell. 71:587-597.

Kaufmann, S.H., and W.C. Earnshaw. 2000. Induction of apoptosis by cancer chemotherapy. Exp Cell Res. 256:42-49.

Kim, H.J., J.Y. Mun, Y.J. Chun, K.H. Choi, and M.Y. Kim. 2001. Bax-dependent apoptosis induced by ceramide in HL-60 cells. FEBS Lett. 505:264-268.

Ko, L.J., and C. Prives. 1996. p53: puzzle and paradigm. Genes Dev. 10:1054-1072. 
Kricker, A., B.K. Armstrong, D.R. English, and P.J. Heenan. 1995. Does intermittent sun exposure cause basal cell carcinoma? a case-control study in Western Australia. Int J Cancer. 60:489-494.

Kubbutat, M.H., S.N. Jones, and K.H. Vousden. 1997. Regulation of p53 stability by Mdm2. Nature. 387:299-303.

Lage, H., H. Helmbach, M. Dietel, and D. Schadendorf. 2000. Modulation of DNA topoisomerase II activity and expression in melanoma cells with acquired drug resistance. Br J Cancer. 82:488-491.

Lane, D.P., and S. Benchimol. 1990. p53: oncogene or anti-oncogene? Genes Dev. 4:1-8.

Lane, D.P., and L.V. Crawford. 1979. T antigen is bound to a host protein in SV40transformed cells. Nature. 278:261-263.

Levine, A.J. 1997. p53, the cellular gatekeeper for growth and division. Cell. 88:323-331.

Li, G., J.A. Bush, and V.C. Ho. 2000. p53-dependent apoptosis in melanoma cells after treatment with camptothecin. J Invest Dermatol. 114:514-519.

Li, G., V.C. Ho, D.L. Mitchell, M.J. Trotter, and V.A. Tron. 1997a. Differentiationdependent p53 regulation of nucleotide excision repair in keratinocytes. Am $J$ Pathol. 150:1457-1464.

Li, G., V.C. Ho, M.J. Trotter, D.E. Horsman, and V.A. Tron. 1995. p53 mutation in metastatic melanomas and primary melanomas from sun-exposed and sunprotected sites. Journal of the European Academy of Dermatology and Venereology. 4:48-53.

Li, G., L. Tang, X. Zhou, V. Tron, and V. Ho. 1998. Chemotherapy-induced apoptosis in melanoma cells is p53 dependent. Melanoma Res. 8:17-23. 
Li, P., D. Nijhawan, I. Budihardjo, S.M. Srinivasula, M. Ahmad, E.S. Alnemri, and X. Wang. 1997b. Cytochrome $\mathrm{c}$ and dATP-dependent formation of Apaf-1/caspase-9 complex initiates an apoptotic protease cascade. Cell. 91:479-489.

Li, P.F., R. Dietz, and R. von Harsdorf. 1999. p53 regulates mitochondrial membrane potential through reactive oxygen species and induces cytochrome c-independent apoptosis blocked by Bcl-2. Embo J. 18:6027-6036.

Liu, X., C.N. Kim, J. Yang, R. Jemmerson, and X. Wang. 1996. Induction of apoptotic program in cell-free extracts: requirement for dATP and cytochrome c. Cell. $86: 147-157$.

Lorenzo, E., C. Ruiz-Ruiz, A.J. Quesada, G. Hernandez, A. Rodriguez, A. Lopez-Rivas, and J.M. Redondo. 2002. Doxorubicin induces apoptosis and CD95 gene expression in human primary endothelial cells through a p53-dependent mechanism. J Biol Chem. 277:10883-10892.

Lotem, J., and L. Sachs. 1993. Hematopoietic cells from mice deficient in wild-type p53 are more resistant to induction of apoptosis by some agents. Blood. 82:1092-1096.

Lowe, S.W. 1995. Cancer therapy and p53. Curr Opin Oncol. 7:547-553.

Lowe, S.W., S. Bodis, A. McClatchey, L. Remington, H.E. Ruley, D.E. Fisher, D.E. Housman, and T. Jacks. 1994. p53 status and the efficacy of cancer therapy in vivo. Science. 266:807-810.

Lowe, S.W., H.E. Ruley, T. Jacks, and D.E. Housman. 1993. p53-dependent apoptosis modulates the cytotoxicity of anticancer agents. Cell. 74:957-967. 
Luu, Y., J. Bush, K.J. Cheung, Jr., and G. Li. 2002. The p53 stabilizing compound CP31398 induces apoptosis by activating the intrinsic Bax/mitochondrial/caspase-9 pathway. Exp Cell Res. 276:214-222.

Luu, Y., and G. Li. 2002. The p53-stabilizing compound CP-31398 enhances ultraviolet-Binduced apoptosis in a human melanoma cell line MMRU. J Invest Dermatol. 119:1207-1209.

Malkin, D., F.P. Li, L.C. Strong, J.F. Fraumeni, Jr., C.E. Nelson, D.H. Kim, J. Kassel, M.A. Gryka, F.Z. Bischoff, M.A. Tainsky, and et al. 1990. Germ line p53 mutations in a familial syndrome of breast cancer, sarcomas, and other neoplasms. Science. 250:1233-1238.

Marchenko, N.D., A. Zaika, and U.M. Moll. 2000. Death signal-induced localization of p53 protein to mitochondria. A potential role in apoptotic signaling. $J$ Biol Chem. $275: 16202-16212$

Medema, J.P., C. Scaffidi, F.C. Kischkel, A. Shevchenko, M. Mann, P.H. Krammer, and M.E. Peter. 1997. FLICE is activated by association with the CD95 death-inducing signaling complex (DISC). Embo J. 16:2794-2804.

Milner, J., and E.A. Medcalf. 1990. Temperature-dependent switching between "wildtype" and "mutant" forms of p53-Val135. J Mol Biol. 216:481-484.

Miyashita, T., M. Harigai, M. Hanada, and J.C. Reed. 1994a. Identification of a p53dependent negative response element in the bcl-2 gene. Cancer Res. 54:3131-3135.

Miyashita, T., S. Krajewski, M. Krajewska, H.G. Wang, H.K. Lin, D.A. Liebermann, B. Hoffman, and J.C. Reed. 1994b. Tumor suppressor p53 is a regulator of bcl-2 and bax gene expression in vitro and in vivo. Oncogene. 9:1799-1805. 
Miyashita, T., and J.C. Reed. 1995. Tumor suppressor p53 is a direct transcriptional activator of the human bax gene. Cell. 80:293-299.

Momand, J., G.P. Zambetti, D.C. Olson, D. George, and A.J. Levine. 1992. The mdm-2 oncogene product forms a complex with the $\mathrm{p} 53$ protein and inhibits $\mathrm{p} 53$-mediated transactivation. Cell. 69:1237-1245.

Moroni, M.C., E.S. Hickman, E.L. Denchi, G. Caprara, E. Colli, F. Cecconi, H. Muller, and K. Helin. 2001. Apaf-1 is a transcriptional target for E2F and p53. Nat Cell Biol. 3:552-558.

Muller, M., C.A. Scaffidi, P.R. Galle, W. Stremmel, and P.H. Krammer. 1998a. The role of p53 and the CD95 (APO-1/Fas) death system in chemotherapy-induced apoptosis. Eur Cytokine Netw. 9:685-686.

Muller, M., S. Strand, H. Hug, E.M. Heinemann, H. Walczak, W.J. Hofmann, W. Stremmel, P.H. Krammer, and P.R. Galle. 1997. Drug-induced apoptosis in hepatoma cells is mediated by the CD95 (APO-1/Fas) receptor/ligand system and involves activation of wild-type p53. J Clin Invest. 99:403-413.

Muller, M., S. Wilder, D. Bannasch, D. Israeli, K. Lehlbach, M. Li-Weber, S.L. Friedman, P.R. Galle, W. Stremmel, M. Oren, and P.H. Krammer. 1998b. p53 activates the CD95 (APO-1/Fas) gene in response to DNA damage by anticancer drugs. $J$ Exp Med. 188:2033-2045.

Muzio, M., A.M. Chinnaiyan, F.C. Kischkel, K. O'Rourke, A. Shevchenko, J. Ni, C. Scaffidi, J.D. Bretz, M. Zhang, R. Gentz, M. Mann, P.H. Krammer, M.E. Peter, and V.M. Dixit. 1996. FLICE, a novel FADD-homologous ICE/CED-3-like protease, is 
recruited to the CD95 (Fas/APO-1) death--inducing signaling complex. Cell. $85: 817-827$

Muzio, M., B.R. Stockwell, H.R. Stennicke, G.S. Salvesen, and V.M. Dixit. 1998. An induced proximity model for caspase-8 activation. J Biol Chem. 273:2926-2930.

Nabeya, Y., F. Loganzo, Jr., P. Maslak, L. Lai, A.R. de Oliveira, G.K. Schwartz, M.L. Blundell, N.K. Altorki, D.P. Kelsen, and A.P. Albino. 1995. The mutational status of p53 protein in gastric and esophageal adenocarcinoma cell lines predicts sensitivity to chemotherapeutic agents. Int J Cancer. 64:37-46.

Nagata, S. 1997. Apoptosis by death factor. Cell. 88:355-365.

Nakanishi, M., Y. Kagawa, H. Takahashi, and H. Matsushime. 1997. Two different bindings of p21 Cdk inhibitor to cyclin/Cdk complex. Leukemia. 11 Suppl 3:356357.

Nakano, K., E. Balint, M. Ashcroft, and K.H. Vousden. 2000. A ribonucleotide reductase gene is a transcriptional target of p53 and p73. Oncogene. 19:4283-4289.

Nakano, K., and K.H. Vousden. 2001. PUMA, a novel proapoptotic gene, is induced by p53. Mol Cell. 7:683-694.

Narita, M., S. Shimizu, T. Ito, T. Chittenden, R.J. Lutz, H. Matsuda, and Y. Tsujimoto. 1998. Bax interacts with the permeability transition pore to induce permeability transition and cytochrome c release in isolated mitochondria. Proc Natl Acad Sci U SA. 95:14681-14686.

Niculescu, A.B., 3rd, X. Chen, M. Smeets, L. Hengst, C. Prives, and S.I. Reed. 1998. Effects of p21(Cip1/Waf1) at both the G1/S and the G2/M cell cycle transitions: 
$\mathrm{pRb}$ is a critical determinant in blocking DNA replication and in preventing endoreduplication. Mol Cell Biol. 18:629-643.

Offer, H., I. Zurer, G. Banfalvi, M. Reha'k, A. Falcovitz, M. Milyavsky, N. Goldfinger, and V. Rotter. 2001. p53 modulates base excision repair activity in a cell cyclespecific manner after genotoxic stress. Cancer Res. 61:88-96.

Oliner, J.D., J.A. Pietenpol, S. Thiagalingam, J. Gyuris, K.W. Kinzler, and B. Vogelstein. 1993. Oncoprotein MDM2 conceals the activation domain of tumour suppressor p53. Nature. 362:857-860.

Oltvai, Z.N., C.L. Milliman, and S.J. Korsmeyer. 1993. Bcl-2 heterodimerizes in vivo with a conserved homolog, Bax, that accelerates programmed cell death. Cell. 74:609619.

Owen-Schaub, L.B., W. Zhang, J.C. Cusack, L.S. Angelo, S.M. Santee, T. Fujiwara, J.A. Roth, A.B. Deisseroth, W.W. Zhang, E. Kruzel, and et al. 1995. Wild-type human p53 and a temperature-sensitive mutant induce Fas/APO-1 expression. Mol Cell Biol. 15:3032-3040.

Pastorino, J.G., S.T. Chen, M. Tafani, J.W. Snyder, and J.L. Farber. 1998. The overexpression of Bax produces cell death upon induction of the mitochondrial permeability transition. $J$ Biol Chem. 273:7770-7775.

Pavletich, N.P., K.A. Chambers, and C.O. Pabo. 1993. The DNA-binding domain of p53 contains the four conserved regions and the major mutation hot spots. Genes Dev. $7: 2556-2564$

Pearson, A.S., F.R. Spitz, S.G. Swisher, M. Kataoka, M.G. Sarkiss, R.E. Meyn, T.J. McDonnell, R.J. Cristiano, and J.A. Roth. 2000. Up-regulation of the proapoptotic 
mediators Bax and Bak after adenovirus-mediated p53 gene transfer in lung cancer cells. Clin Cancer Res. 6:887-890.

Pietenpol, J.A., T. Tokino, S. Thiagalingam, W.S. el-Deiry, K.W. Kinzler, and B. Vogelstein. 1994. Sequence-specific transcriptional activation is essential for growth suppression by p53. Proc Natl Acad Sci U S A. 91:1998-2002.

Polyak, K., Y. Xia, J.L. Zweier, K.W. Kinzler, and B. Vogelstein. 1997. A model for p53induced apoptosis. Nature. 389:300-305.

Pomerantz, J., N. Schreiber-Agus, N.J. Liegeois, A. Silverman, L. Alland, L. Chin, J. Potes, K. Chen, I. Orlow, H.W. Lee, C. Cordon-Cardo, and R.A. DePinho. 1998. The Ink4a tumor suppressor gene product, p19Arf, interacts with MDM2 and neutralizes MDM2's inhibition of p53. Cell. 92:713-723.

Reinke, V., and G. Lozano. 1997. The p53 targets $\mathrm{mdm} 2$ and Fas are not required as mediators of apoptosis in vivo. Oncogene. 15:1527-1534.

Rigel, D.S. 2002. The effect of sunscreen on melanoma risk. Dermatol Clin. 20:601-606.

Rigel, D.S., R.J. Friedman, and A.W. Kopf. 1996. The incidence of malignant melanoma in the United States: issues as we approach the 21st century. J Am Acad Dermatol. $34: 839-847$.

Righetti, S.C., G. Della Torre, S. Pilotti, S. Menard, F. Ottone, M.I. Colnaghi, M.A. Pierotti, C. Lavarino, M. Cornarotti, S. Oriana, S. Bohm, G.L. Bresciani, G. Spatti, and F. Zunino. 1996. A comparative study of p53 gene mutations, protein accumulation, and response to cisplatin-based chemotherapy in advanced ovarian carcinoma. Cancer Res. 56:689-693. 
Rippin, T.M., V.J. Bykov, S.M. Freund, G. Selivanova, K.G. Wiman, and A.R. Fersht. 2002. Characterization of the p53-rescue drug CP-31398 in vitro and in living cells. Oncogene. 21:2119-2129.

Rizos, H., S. Puig, C. Badenas, J. Malvehy, A.P. Darmanian, L. Jimenez, M. Mila, and R.F. Kefford. 2001. A melanoma-associated germline mutation in exon 1beta inactivates p14ARF. Oncogene. 20:5543-5547.

Robles, A.I., N.A. Bemmels, A.B. Foraker, and C.C. Harris. 2001. APAF-1 is a transcriptional target of p53 in DNA damage-induced apoptosis. Cancer Res. 61:6660-6664.

Rodriguez, J., and Y. Lazebnik. 1999. Caspase-9 and APAF-1 form an active holoenzyme. Genes Dev. 13:3179-3184.

Romerdahl, C.A., C. Donawho, I.J. Fidler, and M.L. Kripke. 1988. Effect of ultraviolet-B radiation on the in vivo growth of murine melanoma cells. Cancer Res. 48:40074010.

Rosen, A., and L. Casciola-Rosen. 1997. Macromolecular substrates for the ICE-like proteases during apoptosis. $J$ Cell Biochem. 64:50-54.

Roses, D.F., N.S. Karp, R. Oratz, N. Dubin, M.N. Harris, J. Speyer, A. Boyd, F.M. Golomb, J. Ransohoff, and M. Dugan. 1991a. Survival with regional and distant metastases from cutaneous malignant melanoma. Surg Gynecol Obstet. 172:262268.

Roses, D.F., N.S. Karp, R. Oratz, N. Dubin, M.N. Harris, J. Speyer, A. Boyd, F.M. Golomb, J. Ransohoff, M. Dugan, and et al. 1991b. Survival with regional and 
distant metastases from cutaneous malignant melanoma. Surg Gynecol Obstet. 172:262-268.

Rosse, T., R. Olivier, L. Monney, M. Rager, S. Conus, I. Fellay, B. Jansen, and C. Borner. 1998. Bcl-2 prolongs cell survival after Bax-induced release of cytochrome c. Nature. 391:496-499.

Rozenfeld-Granot, G., J. Krishnamurthy, K. Kannan, A. Toren, N. Amariglio, D. Givol, and G. Rechavi. 2002. A positive feedback mechanism in the transcriptional activation of Apaf-1 by p53 and the coactivator Zac-1. Oncogene. 21:1469-1476.

Saleh, A., S.M. Srinivasula, S. Acharya, R. Fishel, and E.S. Alnemri. 1999. Cytochrome c and dATP-mediated oligomerization of Apaf- 1 is a prerequisite for procaspase-9 activation. J Biol Chem. 274:17941-17945.

Schadendorf, D., R. Herfordt, and B.M. Czarnetzki. 1995. P-glycoprotein expression in primary and metastatic malignant melanoma. $B r J$ Dermatol. 132:551-555.

Schadendorf, D., K. Jurgovsky, M. Worm, and B.M. Czarnetzki. 1994. In vitro sensitivity of human melanoma cells to chemotherapeutic agents and interferons. Melanoma Res. 4:243-249.

Schmitt, C.A., and S.W. Lowe. 1999. Apoptosis and therapy. J Pathol. 187:127-137.

Selivanova, G., T. Kawasaki, L. Ryabchenko, and K.G. Wiman. 1998. Reactivation of mutant p53: a new strategy for cancer therapy. Semin Cancer Biol. 8:369-378.

Serrone, L., and P. Hersey. 1999. The chemoresistance of human malignant melanoma: an update. Melanoma Res. 9:51-58.

Shen, Y., and E. White. 2001. p53-dependent apoptosis pathways. Adv Cancer Res. 82:5584. 
Sherr, C.J. 1998. Tumor surveillance via the ARF-p53 pathway. Genes Dev. 12:29842991.

Sherr, C.J., and J.M. Roberts. 1995. Inhibitors of mammalian G1 cyclin-dependent kinases. Genes Dev. 9:1149-1163.

Shimizu, S., M. Narita, and Y. Tsujimoto. 1999. Bcl-2 family proteins regulate the release of apoptogenic cytochrome $\mathrm{c}$ by the mitochondrial channel VDAC. Nature. 399:483-487.

Skehan, P., R. Storeng, D. Scudiero, A. Monks, J. McMahon, D. Vistica, J.T. Warren, H. Bokesch, S. Kenney, and M.R. Boyd. 1990. New colorimetric cytotoxicity assay for anticancer-drug screening. J Natl Cancer Inst. 82:1107-1112.

Smith, M.L., I.T. Chen, Q. Zhan, I. Bae, C.Y. Chen, T.M. Gilmer, M.B. Kastan, P.M. O'Connor, and A.J. Fornace, Jr. 1994. Interaction of the p53-regulated protein Gadd45 with proliferating cell nuclear antigen. Science. 266:1376-1380.

Soengas, M.S., P. Capodieci, D. Polsky, J. Mora, M. Esteller, X. Opitz-Araya, R. McCombie, J.G. Herman, W.L. Gerald, Y.A. Lazebnik, C. Cordon-Cardo, and S.W. Lowe. 2001. Inactivation of the apoptosis effector Apaf-1 in malignant melanoma. Nature. 409:207-211.

Soussi, T. 2000. The p53 tumor suppressor gene: from molecular biology to clinical investigation. Ann N Y Acad Sci. 910:121-137; discussion 137-129.

Srivastava, S., Z.Q. Zou, K. Pirollo, W. Blattner, and E.H. Chang. 1990. Germ-line transmission of a mutated p53 gene in a cancer-prone family with Li-Fraumeni syndrome. Nature. 348:747-749. 
Stennicke, H.R., Q.L. Deveraux, E.W. Humke, J.C. Reed, V.M. Dixit, and G.S. Salvesen. 1999. Caspase-9 can be activated without proteolytic processing. J Biol Chem. 274:8359-8362.

Symonds, H., L. Krall, L. Remington, M. Saenz-Robles, S. Lowe, T. Jacks, and T. Van Dyke. 1994. p53-dependent apoptosis suppresses tumor growth and progression in vivo. Cell. 78:703-711.

Takimoto, R., W. Wang, D.T. Dicker, F. Rastinejad, J. Lyssikatos, and W.S. el-Deiry. 2002. The mutant p53-conformation modifying drug, CP-31398, can induce apoptosis of human cancer cells and can stabilize wild-type p53 protein. Cancer Biol Ther. 1:47-55.

Tanaka, H., H. Arakawa, T. Yamaguchi, K. Shiraishi, S. Fukuda, K. Matsui, Y. Takei, and Y. Nakamura. 2000. A ribonucleotide reductase gene involved in a p53-dependent cell-cycle checkpoint for DNA damage. Nature. 404:42-49.

Tanner, S., and A. Barberis. 2004. CP-31398, a putative p53-stabilizing molecule tested in mammalian cells and in yeast for its effects on p53 transcriptional activity. $J$ Negat Results Biomed. 3:5.

Tao, W., and A.J. Levine. 1999a. Nucleocytoplasmic shuttling of oncoprotein Hdm2 is required for Hdm2-mediated degradation of p53. Proc Natl Acad Sci U SA. 96:3077-3080.

Tao, W., and A.J. Levine. 1999b. P19(ARF) stabilizes p53 by blocking nucleo-cytoplasmic shuttling of Mdm2. Proc Natl Acad Sci U S A. 96:6937-6941. 
Tishler, R.B., S.K. Calderwood, C.N. Coleman, and B.D. Price. 1993. Increases in sequence specific DNA binding by 553 following treatment with chemotherapeutic and DNA damaging agents. Cancer Res. 53:2212-2216.

Towbin, H., T. Staehelin, and J. Gordon. 1979. Electrophoretic transfer of proteins from polyacrylamide gels to nitrocellulose sheets: procedure and some applications. Proc Natl Acad Sci U S A. 76:4350-4354.

Tron, V.A., M.J. Trotter, T. Ishikawa, V.C. Ho, and G. Li. 1998a. p53-dependent regulation of nucleotide excision repair in murine epidermis in vivo. J Cutan Med Surg. 3:16-20.

Tron, V.A., M.J. Trotter, L. Tang, M. Krajewska, J.C. Reed, V.C. Ho, and G. Li. 1998b. p53-regulated apoptosis is differentiation dependent in ultraviolet B-irradiated mouse keratinocytes. Am J Pathol. 153:579-585.

Unger, T., M.M. Nau, S. Segal, and J.D. Minna. 1992. p53: a transdominant regulator of transcription whose function is ablated by mutations occurring in human cancer. Embo J. 11:1383-1390.

Vogelstein, B., D. Lane, and A.J. Levine. 2000. Surfing the p53 network. Nature. 408:307310.

Walther, W., and U. Stein. 2000. Viral vectors for gene transfer: a review of their use in the treatment of human diseases. Drugs. 60:249-271.

Wang, P., M. Reed, Y. Wang, G. Mayr, J.E. Stenger, M.E. Anderson, J.F. Schwedes, and P. Tegtmeyer. 1994. p53 domains: structure, oligomerization, and transformation. Mol Cell Biol. 14:5182-5191. 
Wang, W., R. Takimoto, F. Rastinejad, and W.S. El-Deiry. 2003. Stabilization of p53 by CP-31398 inhibits ubiquitination without altering phosphorylation at serine 15 or 20 or MDM2 binding. Mol Cell Biol. 23:2171-2181.

Wang, X., M. Gorospe, Y. Huang, and N.J. Holbrook. 1997. p27Kip1 overexpression causes apoptotic death of mammalian cells. Oncogene. 15:2991-2997.

Wang, Y., M. Reed, P. Wang, J.E. Stenger, G. Mayr, M.E. Anderson, J.F. Schwedes, and P. Tegtmeyer. 1993. p53 domains: identification and characterization of two autonomous DNA-binding regions. Genes Dev. 7:2575-2586.

Wani, M.A., Q.Z. Zhu, M. El-Mahdy, and A.A. Wani. 1999. Influence of p53 tumor suppressor protein on bias of DNA repair and apoptotic response in human cells. Carcinogenesis. 20:765-772.

Weber, J.D., L.J. Taylor, M.F. Roussel, C.J. Sherr, and D. Bar-Sagi. 1999. Nucleolar Arf sequesters Mdm2 and activates p53. Nat Cell Biol. 1:20-26.

Weinstein, J.N., T.G. Myers, P.M. O'Connor, S.H. Friend, A.J. Fornace, Jr., K.W. Kohn, T. Fojo, S.E. Bates, L.V. Rubinstein, N.L. Anderson, J.K. Buolamwini, W.W. van Osdol, A.P. Monks, D.A. Scudiero, E.A. Sausville, D.W. Zaharevitz, B. Bunow, V.N. Viswanadhan, G.S. Johnson, R.E. Wittes, and K.D. Paull. 1997. An information-intensive approach to the molecular pharmacology of cancer. Science. 275:343-349.

Wischhusen, J., U. Naumann, H. Ohgaki, F. Rastinejad, and M. Weller. 2003. CP-31398, a novel p53-stabilizing agent, induces p53-dependent and p53-independent glioma cell death. Oncogene. 22:8233-8245. 
Wu, G.S., T.F. Burns, E.R. McDonald, 3rd, W. Jiang, R. Meng, I.D. Krantz, G. Kao, D.D. Gan, J.Y. Zhou, R. Muschel, S.R. Hamilton, N.B. Spinner, S. Markowitz, G. Wu, and W.S. el-Deiry. 1997. KILLER/DR5 is a DNA damage-inducible p53-regulated death receptor gene. Nat Genet. 17:141-143.

Wu, G.S., T.F. Burns, E.R. McDonald, 3rd, R.D. Meng, G. Kao, R. Muschel, T. Yen, and W.S. el-Deiry. 1999. Induction of the TRAIL receptor KILLER/DR5 in p53dependent apoptosis but not growth arrest. Oncogene. 18:6411-6418.

Wu, X., J.H. Bayle, D. Olson, and A.J. Levine. 1993. The p53-mdm-2 autoregulatory feedback loop. Genes Dev. 7:1126-1132.

Wyllie, A.H., J.F. Kerr, and A.R. Currie. 1980. Cell death: the significance of apoptosis. Int Rev Cytol. 68:251-306.

Yu, D., T. Jing, B. Liu, J. Yao, M. Tan, T.J. McDonnell, and M.C. Hung. 1998. Overexpression of ErbB2 blocks Taxol-induced apoptosis by upregulation of p21Cip1, which inhibits p34Cdc2 kinase. Mol Cell. 2:581-591.

Yu, J., Z. Wang, K.W. Kinzler, B. Vogelstein, and L. Zhang. 2003. PUMA mediates the apoptotic response to p53 in colorectal cancer cells. Proc Natl Acad Sci U S A. 100:1931-1936

Yu, J., L. Zhang, P.M. Hwang, K.W. Kinzler, and B. Vogelstein. 2001. PUMA induces the rapid apoptosis of colorectal cancer cells. Mol Cell. 7:673-682.

Zanon, M., A. Piris, I. Bersani, C. Vegetti, A. Molla, A. Scarito, and A. Anichini. 2004. Apoptosis protease activator protein-1 expression is dispensable for response of human melanoma cells to distinct proapoptotic agents. Cancer Res. 64:7386-7394. 
Zhang, D., M.D. Berry, I.A. Paterson, and A.A. Boulton. 1999. Loss of mitochondrial membrane potential is dependent on the apoptotic program activated: prevention by R-2HMP. J Neurosci Res. 58:284-292.

Zhang, Y., Y. Xiong, and W.G. Yarbrough. 1998. ARF promotes MDM2 degradation and stabilizes p53: ARF-INK4a locus deletion impairs both the $\mathrm{Rb}$ and $\mathrm{p} 53$ tumor suppression pathways. Cell. 92:725-734.

Zhou, J., J. Ahn, S.H. Wilson, and C. Prives. 2001. A role for p53 in base excision repair. Embo J. 20:914-923.

Ziegler, A., A.S. Jonason, D.J. Leffell, J.A. Simon, H.W. Sharma, J. Kimmelman, L. Remington, T. Jacks, and D.E. Brash. 1994. Sunburn and p53 in the onset of skin cancer. Nature. 372:773-776.

Zou, H., Y. Li, X. Liu, and X. Wang. 1999. An APAF-1.cytochrome c multimeric complex is a functional apoptosome that activates procaspase-9. J Biol Chem. 274:1154911556. 